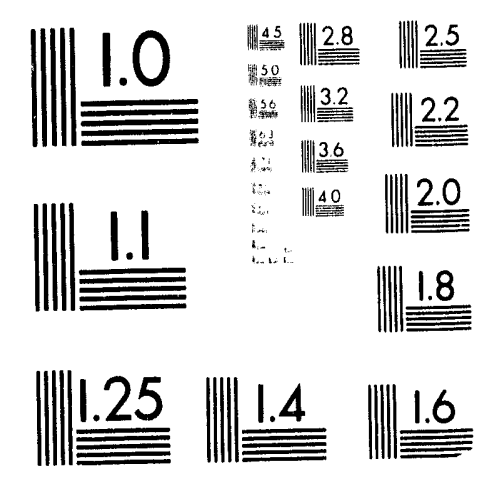


is

$1802 \% 1,43$

OSTI

\section{Uranium Mill TaILINGs Remedial ACtion PROJECT ENVIRONMENTAL Protection IMPLementation Plan}

October 1993

\section{DISCLAIMER}

This report was prepared as an account of work sponsored by an agency of the United States Government. Neither the United States Government nor any agency thereof, nor any of their employees, makes any warranty, express or implied, or assumes any legal liability or responsibility for the accuracy, completeness, or usefulness of any information, apparatus, product, or process disclosed, or represents that its use would not infringe privately owned rights. Reference herein to any specific commercial product, process, or service by trade name, trademark, manufacturer, or otherwise does not necessarily constitute or imply its endorsement, recom. mendation, or favoring by the United States Government or any agency thereof. The views and opinions of authors expressed herein do not necessarily state or reflect those of the United States Government or any agency thereof. 


\section{INTENDED FOR PUBLIC RELEASE}

This report has been reproduced from the best available copy. Available in paper copy and microfiche.

Number of pages in this report: $\mathbf{5 8}$

DOE and DOE contractors can obtain copies of this report from:

Office of Scientific and Technical Information

P.O. Box 62

Oak Ridge, TN 37831

(615) 576-8401

This report is publicly available from:

National Technical Information Service

Department of Commerce

5285 Port Royal Road

Springfield, VA 22161

(703) 487-4650 
URANIUM MILL TAILINGS REMEDIAL ACTION PROJECT

ENVIRONMENTAL PROTECTION IMPLEMENTATION PLAN

SIGNATURE PAGE

Prepared By:

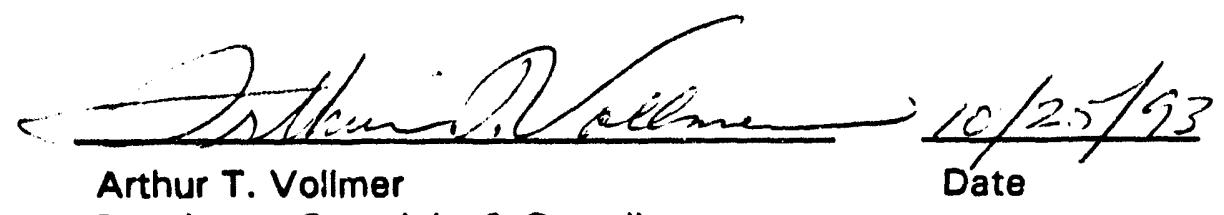

Regulatory Oversight \& Compliance

Support Manager

Jacobs Engineering Group Inc.

Reviewed By:

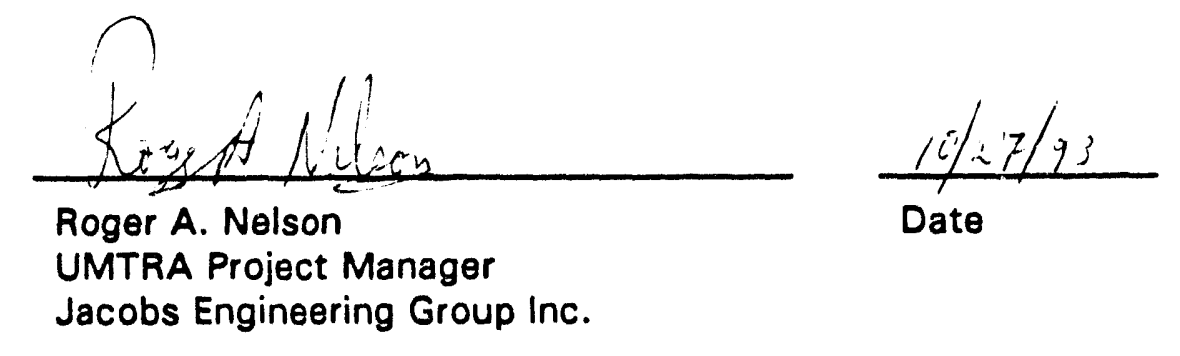

Concurrence By:
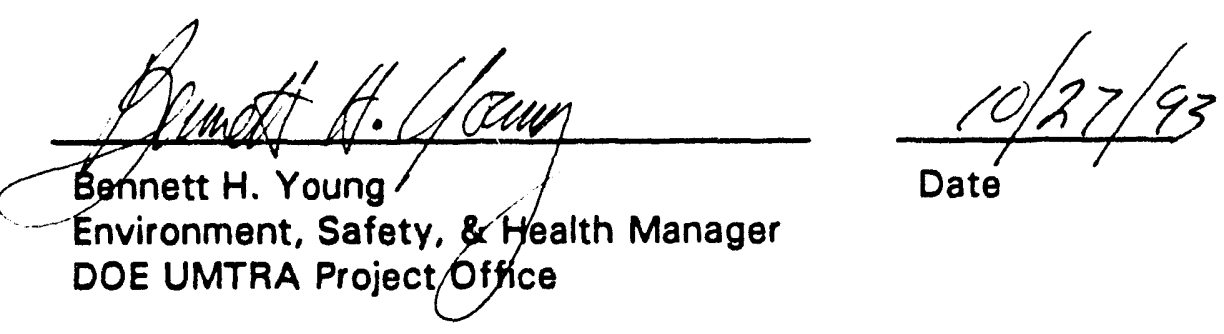

Environment, Safety, \& Health Manager

DOE UMTRA Project Office

Approved By:
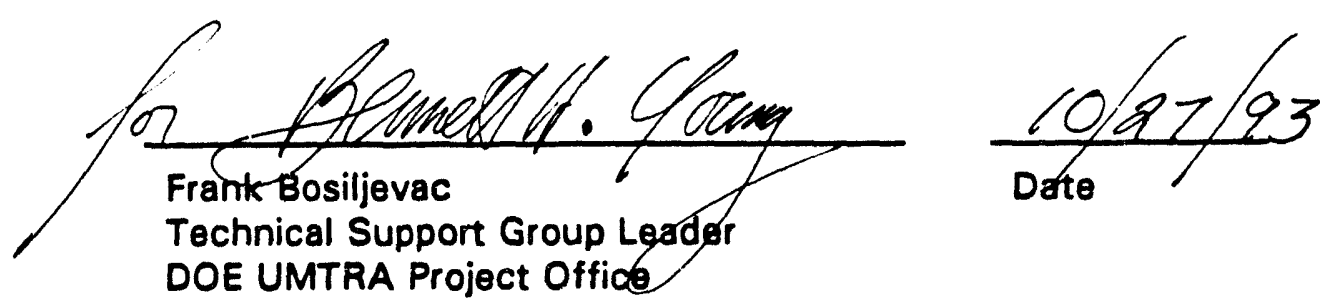
URANIUM MILL TAILINGS REMEDIAL ACTION PROJECT ENVIRONMENTAL PROTECTION IMPLEMENTATION PLAN

October 1993

This report supersedes report no. UMTRA-DOE/AL-150128.0000

Prepared for

U.S. Department of Energy UMTRA Project Office

Albuquerque Operations Office

Prepared by

Jacobs Engineering Group Inc.

Albuquerque, New Mexico 


\section{TABLE OF CONTENTS}

Section

Page

1.0 GENERAL DESCRIPTION OF THE UMTRA PROJECT ENVIRONMENTAL

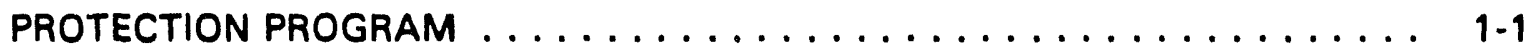

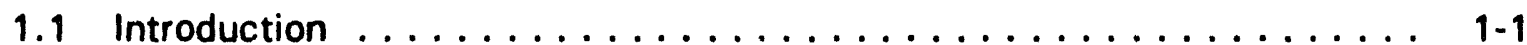

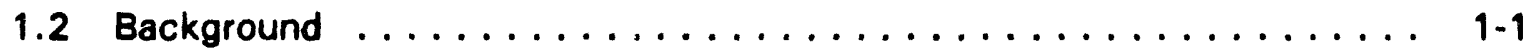

1.3 Goals and objectives ........................ 1-3

1.4 Current environmental protection program ............... 1-6

1.4.1 Program summary . . . . . . . . . . . . . . . . . . . 1-6

1.4.2 DOE Headquarters baseline environmental audit . . . . . . . . 1.8

1.4.3 DOE Headquarters environmental management audit ........ 1-8

1.5 Organization, roles, and responsibilities .................. 1-9

1.5.1 DOE and the UMTRA Project Office .............. 1-11

1.5.2 Contractor organizations ................. 1-13

1.5.2.1 Technical Assistance Contractor ............ 1-13

1.5.2.2 Remedial Action Contractor ... . . . . . . . . . . 1-15

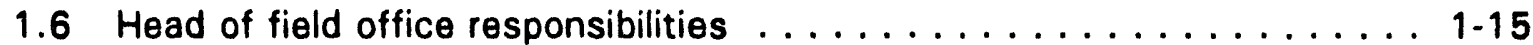

1.7 Resource and schedule surrimary . . . . . . . . . . . . . . 1-20

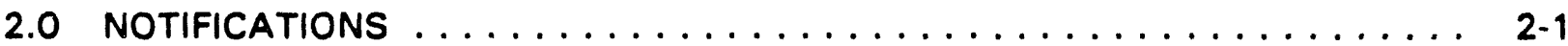

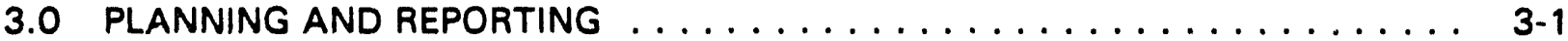

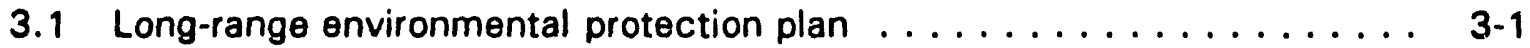

3.2 Annual site environmental report . . . . . . . . . . . . . . . 3-1

3.3 OMB Circular A-106 ....................... 3-2

4.0 SPECIAL PROGRAMS $\ldots \ldots \ldots \ldots \ldots \ldots \ldots \ldots \ldots \ldots \ldots \ldots \ldots \ldots$ 4-1

4.1 Groundwater protection management program . . . . . . . . . . . . . 4 4-1

4.2 Waste minimization/pollution prevention awareness program . . . . . . 4-2

4.3 ES\&H operating envelope program ................. 4-3

5.0 ENVIRONMENTAL MONITORING PROGRAMS $\ldots \ldots \ldots \ldots \ldots \ldots \ldots \ldots$

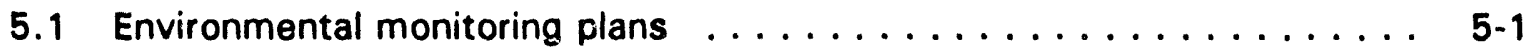

5.2 Environmental monitoring activities ................ 5-1

6.0 GUALITY ASSURANCE AND DATA VERIFICATION $\ldots \ldots \ldots \ldots \ldots \ldots \ldots$

6.1 Quality assurance program ..................... 6-1

6.2 Laboratory certification ...................... 6-1

6.3 DOE Laboratory QA program for radioactive material $\ldots \ldots \ldots \ldots \ldots$ 6-2

6.4 Independent data verification $\ldots \ldots \ldots \ldots \ldots \ldots \ldots \ldots \ldots \ldots$

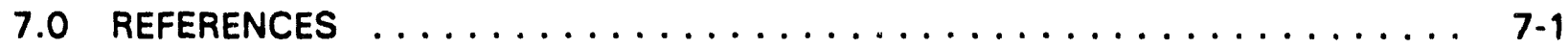

ATTACHMENT A ENVIRONMENTAL PROTECTION AT SURFACE REMEDIAL ACTION SITES 


\section{LIST OF FIGURES}

Figure

Page

1.1 UMTRA Project site locations . . . . . . . . . . . . . . . . . 1-2

1.2 UMTRA Project environmental, safety and health goal statement . . . . . . . 1-5

1.3 Hierarchy of UMTRA Project environmental program plans and procedures . . 1-7

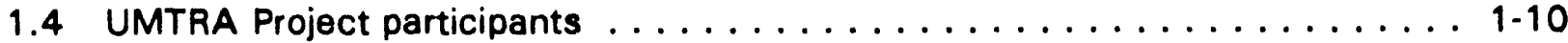

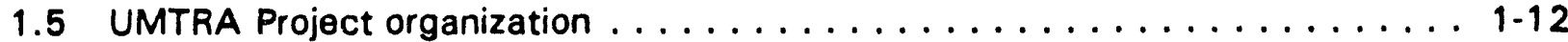

1.6 UMTRA Project Technical Assistance Contractor organization . . . . . . . . . 1-14

1.7 UMTRA Project Remedial Action Contractor organization . . . . . . . . . . . 1-16

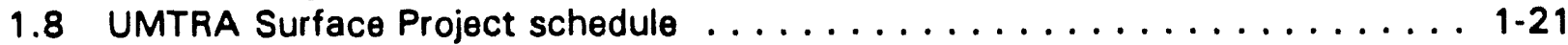

1.9 UMTRA Surface Project total estimated cost $\ldots \ldots \ldots \ldots \ldots \ldots \ldots \ldots$. . . . . . 22

\section{LIST OF TABLES}

Table

Page

1.1 UMTRA Project environmental program elements $\ldots \ldots \ldots \ldots \ldots \ldots$

6.1 UMTRA Project contract laboratories $\ldots \ldots \ldots \ldots \ldots \ldots \ldots \ldots \ldots \ldots$ 


\section{LIST OF ACRONYMS AND ABBREVIATIONS}

Acronym

AEMR

DOE-AL

ALARA

DOE

DOE-HO

DOT

$\mathrm{EH}-1$

EH-24

EM

EMP

EPA

EPIP

ES\&H

FY

GJPO

LTSP

mrem

NEPA

NPDES

NRC

$O M B$

ORNL

PO

QA

QAPP

Ra-226

RAC

RAP

RRM

TAC

UMTRA

UMTRCA

WM/PPAP

\section{Definition}

Annual Environmental Monitoring Report

DOE Albuquerque Field Office

as low as reasonably achievable

U.S. Department of Energy

DOE Headquarters

U.S. Department of Transportation

DOE Assistant Secretary for Environment, Safety, and Health

DOE Office of Environmental Audit

DOE Office of Environmental Restoration and Waste Management

Environmental Monitoring Plan

U.S. Environmental Protection Agency

Environmental Protection Implementation Plan

environment, safety, and health

fiscal year

Grand Junction Projects Office

Long-Term Surveillance Plan

millirem

National Environmental Policy Act

National Pollutant Discharge Elimination System

U.S. Nuclear Regulatory Commission

Office of Management and Budget

Oak Ridge National Laboratory

Project Office

quality assurance

Quality Assurance Program Plan

radium-226

Remedial Action Contractor

remedial action plan

residual radioactive material

Technical Assistance Contractor

Uranium Mill Tailings Remedial Action

Uranium Mill Tailings Radiation Control Act of 1978

Waste Minimization/Pollution Prevention Awareness Program 


\subsection{GENERAL DESCRIPTION OF THE UMTRA PROJECT ENVIRONMENTAL PROTECTION PROGRAM}

\section{$1.1 \quad$ INTRODUCTION}

The Uranium Mill Tailings Remedial Action (UMTRA) Project Environmental Protection Implementation Plan (EPIP) has been prepared in accordance with the requirements of the U.S. Department of Energy (DOE) Order 5400.1. The UMTRA EPIP covers the time period of November 9, 1993, through November 8,1994 . It will be updated annually. Its purpose is to provide management direction to ensure that the UMTRA Project is operated and managed in a manner that will protect, maintain, and where necessary, restore environmental quality, minimize potential threats to public health and the environment, and comply with environmental regulations and DOE policies.

\subsection{BACKGROUND}

The Uranium Mill Tailings Radiation Control Act of 1978 (UMTRCA), 42 U.S.C. $\$ 7922$ et seq., authorizes the DOE to undertake remedial actions at 24 designated inactive uranium processing sites and associated vicinity properties. As a result, the UMTRA Project was formed and placed under the direction of the DOE Albuquerque Operations Office (DOE-AL). The UMTRCA directs that "every reasonable effort be made to provide for stabilization, disposal and control of the tailings in a safe and environmentally sound manner to ensure public health, safety and welfare."

The 24 designated inactive uranium mill tailings sites are located in 11 states and on Indian lands. Figure 1.1 depicts the locations of these sites. Although the 24 UMTRA sites are geographically separate, they are considered a single installation for purposes of administration and environment, safety, and health program (ES\&H) implementation. The UMTRCA currently terminates authorization to conduct the surface program at the end of fiscal year (FY) 1996.

In addition, there are over 5000 vicinity properties being remediated in conjunction with the designated sites. Remediation of the vicinity properties is administered and budgeted through the UMTRA Project Office (PO). Most of these remediation activities are performed in Grand Junction, Colorado, by the DOE Grand Junction Projects Office (GJPO), which is also under the direction of the DOE-AL. The remainder of the vicinity property remediation is performed by MK-Ferguson, the UMTRA Remedial Action Contractor (RAC). Vicinity property remediation handled by GJPO will be covered in the GJPO EPIP (DOE, 1993a). Only the implementation of the environmental protection program for the designated inactive mill sites and remaining vicinity properties is discussed in the UMTRA EPIP. 


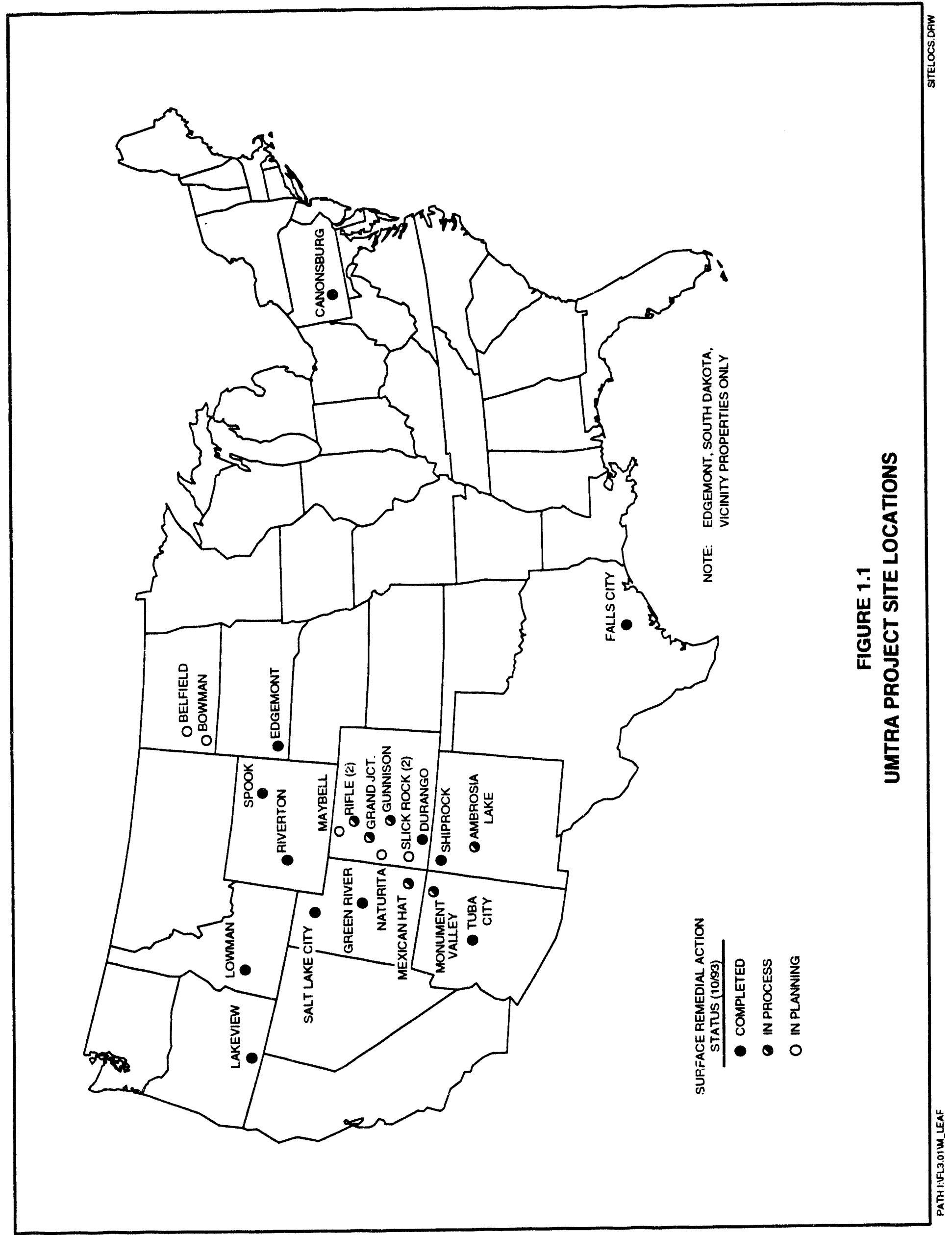


The purpose of the remedial actions is to stabilize and control the uranium mill tailings and other residual radioactive materials (RRM) in a safe and environmentally sound manner in order to minimize radiation health hazards to the public. Pursuant to the UMTRCA, the remedial actions undertaken by the DOE are to be accomplished:

- With the full participation of the affected states and Indian tribes.

- In accordance with standards issued by the U.S. Environmental Protection Agency (EPA) for the UMTRA Project.

- With the concurrence of the U.S. Nuclear Regulatory Commission (NRC).

The EPA established health and environmental protection standards (40 CFR Part 192) to control radiation emissions and to remediate and prevent further contamination of groundwater beneath and in the vicinity of inactive uranium processing sites, uranium mill tailings piles, and disposal cells. The EPA has proposed groundwater protection standards (EPA, 1987) that call for the DOE to either 1) document, for each affected site, that the groundwater quality meots the stated standards without remediation, or 2) remediate the contaminated groundwater until it meets the applicable standards.

The UMTRA-Surface Project has been designated by the DOE as a major system acquisition under the non-defense Environmental Restoration Program because of its importance and budget requirements. Surface remedial action is actively under way or completed at most sites (Figure 1.1). The UMTRA-Groundwater Project, which is a separate major project, is in its early planning stages.

While the sites for the UMTRA-Groundwater Project are the same as for the UMTRA-Surface Project, the extent of groundwater remediation required at each site and the priorities for groundwater cleanup will be determined after each site has been assessed and comments from affected states, tribes, and the public have been received. Unlike the 1996 limit on the surface remedial action program, the UMTRCA does not limit the period for conducting groundwater restoration.

\subsection{GOALS AND OBJECTIVES}

The UMTRA Project is an environmental remediation program designed to minimize or eliminate environmental and public health hazards. The UMTRA Project's overall goal is to clean up and control tailings from inactive uranium mills in a safe and environmentally sound manner to eliminate current and potential environmental and public health hazards associated with these tailings. These hazards include exposure to radium, radon, thorium, uranium, and other contaminants associated with the processing of uranium mill tailings.

Specifically, the objectives of the UMTRA-Surface and UMTRA-Groundwater projects are to: 
- Reduce or eliminate public health and environmental risks from radioactive, hazardous, and toxic constituents in uranium mill tailings and tailings-contaminated materials by meeting the EPA standards in 40 CFR Part 192.

- Ensure that environmental protection is adequately addressed in the selertion and implementation of remedial actions, and that provisions of the National Environmental Policy Act (NEPA)(42 U.S.C.A. \$4321), as implemented by the DOE in 10 CFR Part 1021, are satisfied.

- Perform remedial actions at the designated inactive uranium processing sites and vicinity properties in a safe and environmentally sound manner and in accordance with all applicable Federal, tribal, state, and local ES\&H requirements.

- Return all former processing sites to a condition suitable for unrestricted use, except for that portion necessary to contain any tailings disposal cell that may remain.

- Prepare long-term surveillance plans (LTSP) for tailings disposal sites and have each site included under the general NRC license in accordance with 10 CFR Part 40.

The UMTRA PO's environmental policy is to conduct Project operations in compliance with all applicable Federal, state, and local environmental regulations, laws, DOE Orders, and other requirements, as required by the DOE-AL Environmental Policy Statement (DOE, 1992a). The PO is committed to providing sound environmental management to all Project sites; correcting existing environmental problems before they deviate from regulatory requirements or pose a threat to the quality of the environment; and minimizing the generation of contaminants, wastes, and other residual materials requiring disposal or release to the environment. The UMTRA PO has stated its commitment to sound environmental management in the UMTRA Project ES\&H goal statement (Figure 1.2), initially issued in June 1991 and most recently revised in May 1992 (DOE, 1992b).

In addition, the UMTRA PO has set three environmental goals in the UMTRA Project ES\&H plan (DOE, 1992c):

1. Environmental Protection Goał-Environmental releases from Project operations should be kept below permit and other applicable requirements.

2. Environmental Compliance Goal-There should be no violations of environmental permits or regulations.

3. Environmental Restoration Goal-Remedial actions at processing sites and vicinity properties should result in the 40 CFR Part 192 cleanup standard requirements being met at a minimum. 
The DOE's Uranium Mill Tailings Remedial Action (UMTRA) Project is a remediation and environmental protection program. The Project's congressionally mandated mission is to clean up and control residual radioactive materials from designated inactive uranium processing sites and to eliminate present and future environmental health hazards that may result from those materials. The UMTRA Project's goal is to achieve its mission in a manner which protects public health and safety and the environment; ensures the safety and health of workers; and meets or exceeds the requirements of all Federal, state, and local laws, regulations, orders, and permits, utilizing best management practices. To achieve this goal, the UMTRA Project Office has prepared and is implementing an UMTRA Project Environmental, Health, and Safety Plan.

The UMTRA Project remains firmly committed to implementing national envir onmental protection policies and goals while following the most technologically advanced safety and health policies and goals. Accordingly, the UMTRA Project Office's policy is to conduct operations in compliance with both the letter and the spirit of applicable environmental, safety and health statutes, regulations, and standards and to strive for excellence rather than just compliance. In oddition, the UMTRA Project is committed to sound environmental management and worker safety practices; minimizing the risks to the environment, the public, and workers; and anticipating and addressing potential problems before they pose a threat to the environment or the public.

The UMTRA Project Office is committed to undertaking appropriate measures to minimize the generation of contaminants, wastes, and other residual materials requiring disposal or release to the environment through source reduction, recycling, treatment, and pollution prevention.

Protection of the environment, workers, and the public are of paramount importance to the DOE and the UMTRA Project. Project activities have always recognized this, and as a result, the Project experiences a level of public trust not evident in many environmental restoration endeavors. It is the UMTRA Project Office's policy that its contractors shall incorporate this commitment to worker safety and environmental management in all of their activities. The Project Office requires its contractors to conduct their operations in an environmentally sound and safe manner that keeps the risks to the environment, workers, and the public as low as reasonably achievable and actively oversees contractors' activities to ensure compliance with this policy.

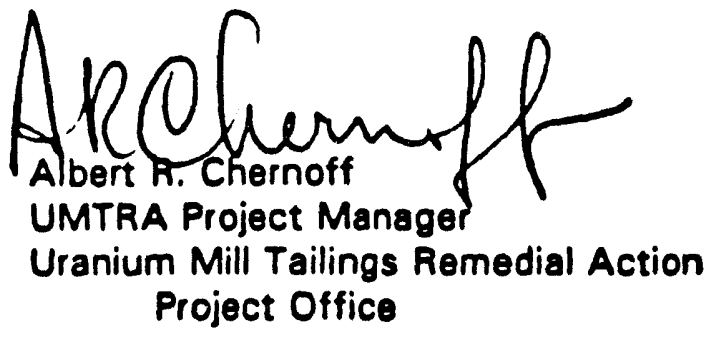

May 1992

FIQURE 1.2

UMTRA PROJECT ENVIRONMENTAL, SAFETY AND HEALTH GOAL STATEMENT 


\subsection{CURRENT ENVIRONMENTAL PROTECTION PROGRAM}

\subsubsection{Program summary}

The relationship of the various elements of the UMTRA Project environmental protection program, as reflected in the various compliance and monitoring plans and guidance documents, is presented in Figure 1.3 and the schedule for their review and periodic revision is presented in Table 1.1. The UMTRA PO has implemented all environmental protection program elements required by DOE 5400.1.

Table 1.1 UMTRA Project environmental program elements

\begin{tabular}{ll}
\hline \multicolumn{1}{c}{ Document } & \multicolumn{1}{c}{ Review and revision cycle } \\
\hline $\begin{array}{l}\text { UNiTiRA Project ES\&H goal statement } \\
\text { Waste minimization pollution prevention } \\
\text { awareness program plan }\end{array}$ & Annual review. \\
UMTRA Project ES\&H plan & Annual review; update every 3 vears. \\
$\begin{array}{l}\text { Groundwater protection management } \\
\text { program plan }\end{array}$ & Annual review; as needed. \\
Environmental monitoring plan & Annual review; update every 3 years. \\
UMTRA Project five-year plan & Annual review; update every 3 years. \\
\hline
\end{tabular}

The UMTRA Project ES\&H goal statement (DOE, 1992b) is discussed in Section 1.3.

The UMTRA PO has in place an UMTRA Project ES\&H plan (DOE, 1992c) that directs the PO's Technical Assistance Contractor (TAC), Jacobs Engineering Group Inc., and the RAC to implement ES\&H policies and goals. The ES\&H plan describes the UMTRA Project ES\&H standards, program requirements, radiation control and monitoring, environmental monitoring, and industrial hazards control program. The ES\&H plan is periodically revised to reflect current guidelines and experience gained.

To better assist the PO in meeting its ES\&H goals, the UMTRA Project ES\&H Committee was established in FY1992. The ES\&H Committee, which is chaired by the UMTRA PO ES\&H Manager and has TAC, RAC, and GJPO representatives, meets monthly. One of the responsibilities of the Committee is to deal with environmental protection issues affecting the Project. Other environmental protection program elements are discussed in greater detail in Sections 2.0 through 6.0 . 


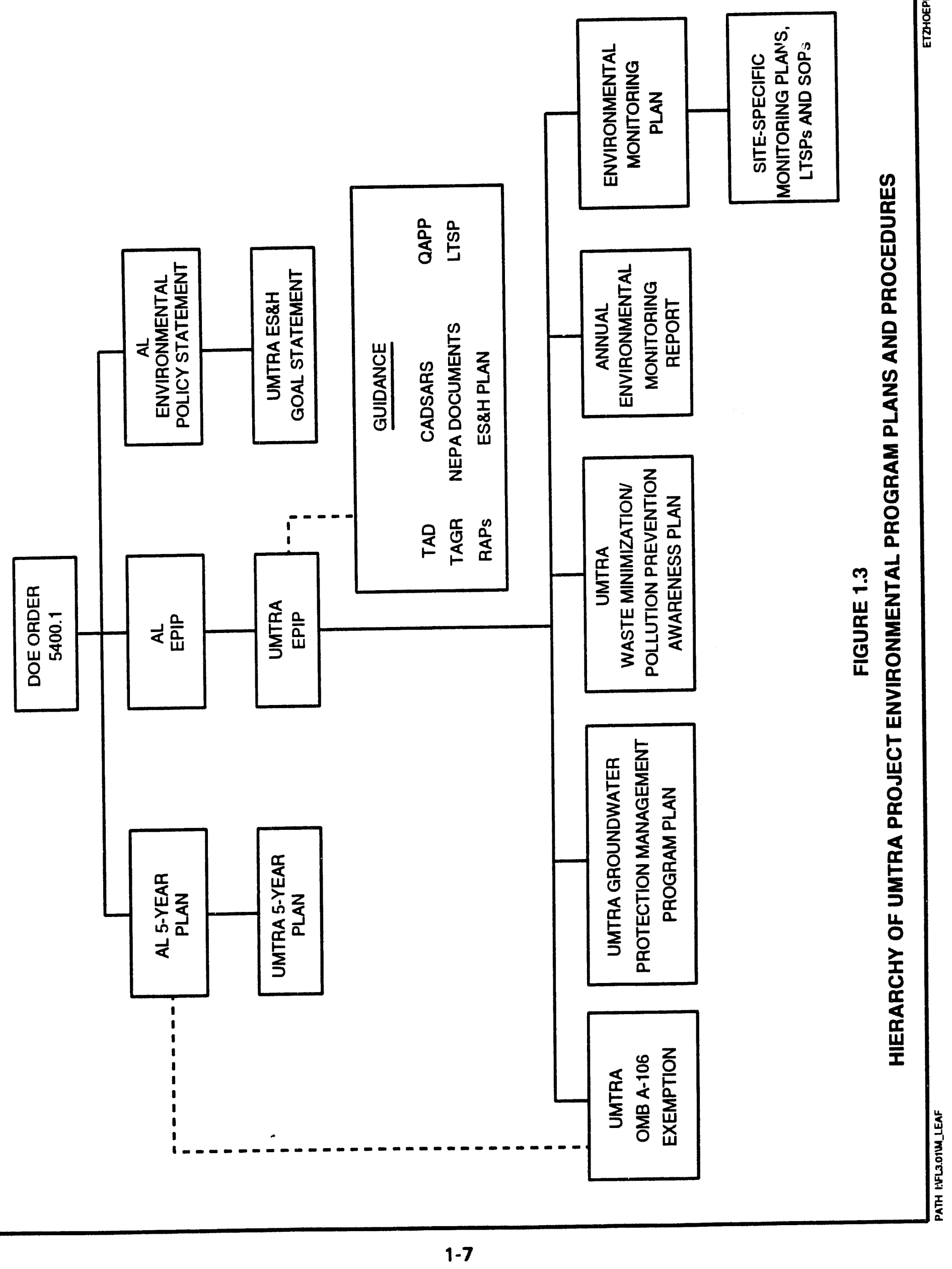




\subsubsection{DOE Headauarters baseline environmental audit}

The DOE Office of Environmental Audit (EH-24) conducted a baseline environmental audit of the UMTRA Project in June 1991. The scope of the audit covered all areas of environmental activities and waste management operations, with the exception of NEPA compliance. Compliance with Federal, state, and local regulations, DOE Orders, and internal facility requirements was assessed, along with adherence to best management practices.

The baseline environmental audit identified 48 findings (DOE, 1991a). The findings were divided between 32 compliance findings and 16 best management practices. None of these findings, however, reflected situations that presented an immediate danger to the public health or the environment.

The UMTRA PO responded with an action plan (DOE, 1991b) that defines responsibilities and describes the organization and management structures to be used to implement the action plan. The plan identifies actions that will correct the deficiencies found by the audit as well as the underlying root causes. Implementation of the action plan has resulted in significant improvement in UMTRA Project compliance with environmental regulations.

By the end of FY1993, the UMTRA Project had completed 92 percent of the baseline environmental audit corrective actions. The four remaining corrective actions will be completed during FY 1994.

\subsubsection{DOE Headauarters environmental management audit}

EH-24 conducted an environmental management audit of the UMTRA Project during October and November 1992. The scope of the audit was comprehensive and covered all areas of environmental management by the UMTRA PO and GJPO, except for NEPA implementation.

The environmental management audit identified 18 findings, broken into 11 compliance findings and 7 best management findings (DOE, 1993b). No findings presented immediate danger to the environment or public health. Overall, the conclusion was that the UMTRA Project has made excellent progress in implementing and developing environmental protection programs.

An action plan was prepared to address the findings and identify corrective actions (DOE, 1993c). The plan assigns responsibility to the affected organization, along with a designated DOE UMTRA oversight person. The action plan was approved by the DOE Office of Environmental Restoration prior to release to the Assistant Secretary for Environment, Safety, and Health (EH-1). All actions were assigned a priority ranking according to priority definitions developed for Tiger Team action plans. Priority 1 action items will be aggressively pursued by the UMTRA PO. 
The key findings and corrective actions for each can be summarized as follows:

- Program evaluation and oversight - Program evaluation and oversight are not sufficient to ensure accurate monitoring of issues and organizational effectiveness including a lack of formalized self-assessment programs, deficiencies in performance indicators and trending programs, and inadequate ES\&H appraisal programs.

The UMTRA PO has submitted a draft self-assessment plan and implementation schedule to DOE-AL. Assessable units have been identified and performance objectives and criteria are being developed. To correct deficiencies in the performance indicators and trending programs, the UMTRA PO will develop the UMTRA-specific performance indicators and implement a program that includes root cause analysis, tracking, trending, communicating performance, and lessons learned. To improve ES\&H appraisal programs, UMTRA PO and GJPO will assist DOE-AL in scheduling and performing management and functional appraisals. For internal appraisal programs, the UMTRA PO has developed a new audit tracking system to be used for all audits and assessments of projec: activities.

- Organizational arrangement - The existing organizational arrangement and reporting mechanism between the GJPO and UMTRA PO has created some confusion.

Management representatives from the UMTRA PO and GJPO will clarify the roles, responsibilities, and chain-of-command relationships among all parties for activities associated with the UMTRA Project.

- Resources and training - Staffing levels within the UMTRA Project are not sufficient to ensure environmental performance goals are being met; a formalized training system for UMTRA participants has not been adequately developed.

The UMTRA Project is seeking unique ways to meet staffing problems and training requirements. In response to this audit, the Office of Environmental Restoration transferred one of its employees to the UMTRA Project.

By adhering to these corrective actions, environmental programs on the UMTRA Project will be significantly enhanced.

\subsection{ORGANIZATION, ROLES, AND RESPONSIBILITIES}

This section presents information on the organization and management structure of the DOE offices and contractor organizations participating in the UMTRA Project, including environmental protection activities. Figure 1.4 shows the overall organizational relationships of the UMTRA Project participants. 


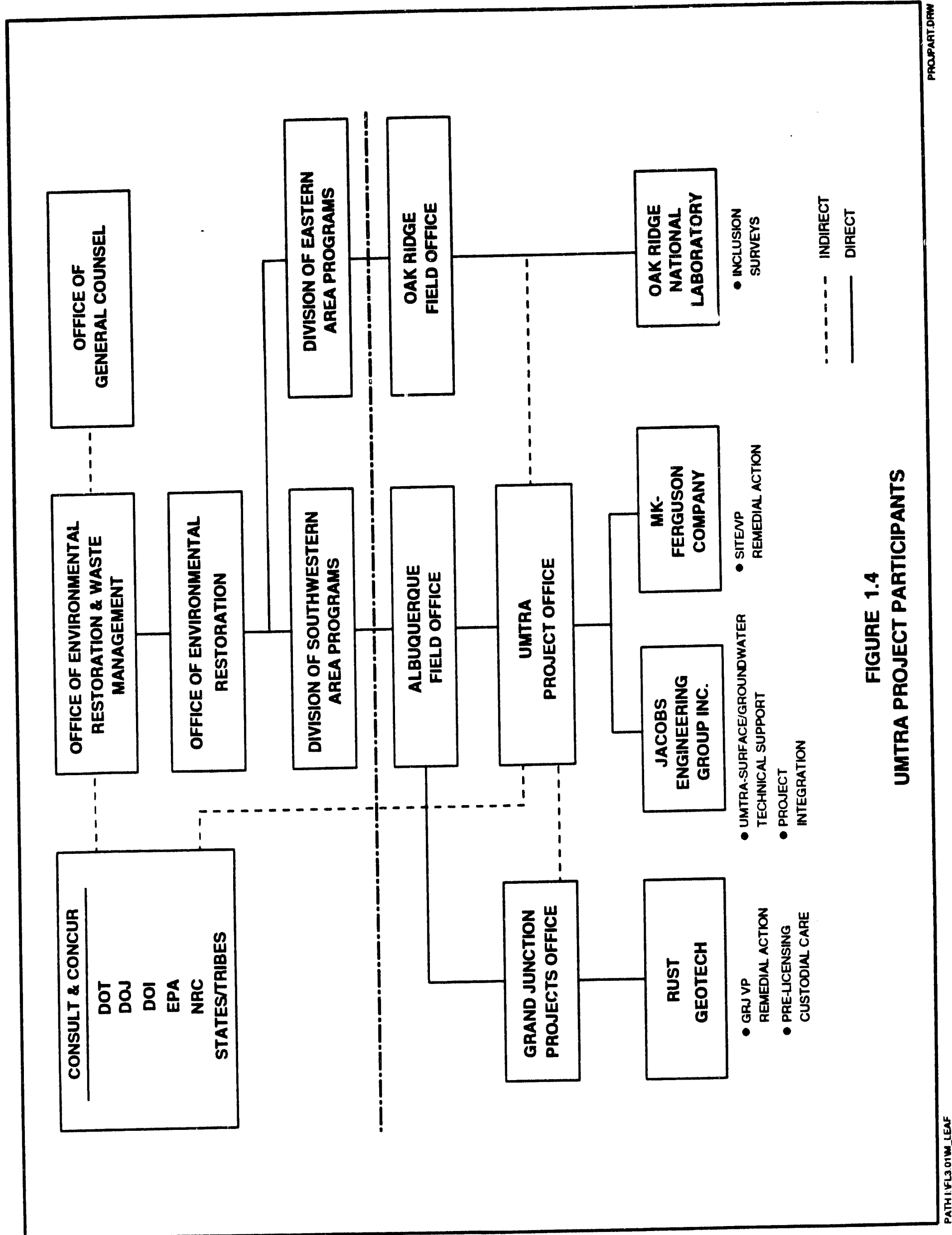




\subsubsection{DOE and the UMTRA Project Office}

The DOE Assistant Secretary for Environmental Restoration and Waste Management has full responsibility and authority for the management, planning, and conduct of UMTRA-Surface and UMTRA-Groundwater Project activities. The DOE's Office of Environmental Restoration and Waste Management's Division of Off-Site Remediation has been assigned Headquarters' responsibilities for the program. The Division Director serves as the Program Manager.

The DOE-AL Manager has been assigned the responsibility and authority for the field management of the Project, which includes the line management authority, responsibility, and accountability for overall Project management and contract administration in a manner consistent with approved legislation, scope, and baselines. Under the current DOE-AL organization and structure, responsibility for management of the Project within the DOE-AL has been assigned to the Assistant Manager for Energy and Special Programs, who established a dedicated PO. The DOE's day-to-day responsibility for planning, coordinating, and conducting remedial actions at the uranium mill tailings sites and associated vicinity properties hias been assigned to the UMTRA PO. Matrix support available to the UMTRA Project Manager, as required, from the DOE-AL organization includes legal, procurement, budget, finance, quality assurance (QA), property management, health and safety, environmental protection, safeguards and security, and public affairs.

The policy and guidance for carrying out the mission of the UMTRA Project are provided by the UMTRA PO. However, some of the vicinity-property-related portions of the UMTRA mission are carried out by the GJPO and by Oak Ridge National Laboratory (ORNL).

The organization, operation, and responsibilities of the UMTRA PO are based on a minimally staffed office, with DOE-AL matrix support (Figure 1.5). The UMTRA PO is responsible for making key Project decisions and for managing the contractors engaged to do the actual work. The UMTRA PO is accountable to DOE-AL and DOE-Headquarters (DOE-HO) management for the successful accomplishment of the Project.

The UMTRA PO Manager and Deputy Manager are supported by three Group Leaders. Within the UMTRA PO, line management is responsible for ES\&H compliance, from the Project Manager, and through the Deputy Project Manager and the Engineering and Construction Group. The Technical Support Group provides Project ES\&H oversight, while the DOE-AL Office of Environment, Safety, and Health has an independent oversight role that involves defining requirements and auditing for compliance.

The Engineering and Construction Group Leader is responsible for managing remedial action planning and execution at all UMTRA Project sites, including construction oversight, design review, cost control, interface with the NRC and 


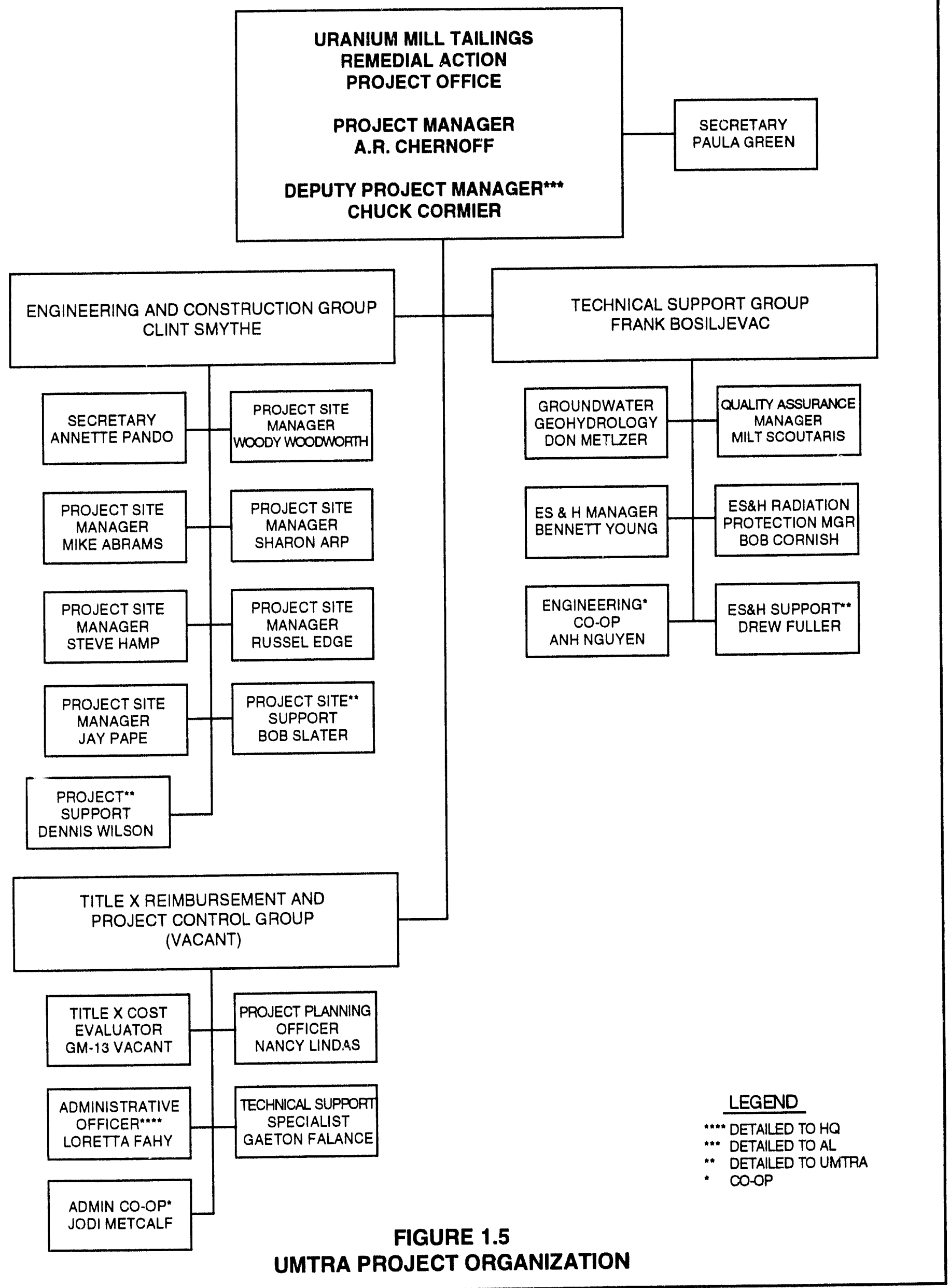


the participating states and tribes, and site/vicinity property management. The Engineering and Construction Group is considered the line organization, and is, therefore, accountable for compliance with ES\&H regulations.

The Technical Support Group Leader is responsible for managing technical support functions, including hydrology and geohydrology, ES\&H oversight, QA, and NEPA documentation. The Project Control Group Leader is responsible for managing project activities involving budget, schedule, finance, administration, personnel, real and personal property management, state cooperative agreements, and the Project five-year plan (DOE, 1993d).

\subsubsection{Contractor organizations}

For the UMTRA-Surface Project, the UMTRA PO is assisted by the TAC and RAC, a vicinity property Inclusion Survey Contractor, and a Grand Junction vicinity property RAC. The Grand Junction RAC, RUST Geotech, and the Inclusion Survey Contractor, ORNL, are managed by the GJPO and their responsibilities are discussed in the GJPO EPIP (DOE, 1993a). The TAC is the only contract organization assisting the UMTRA PC with the UMTRAGroundwater rroject at the present time, providing technical assistance and Project integration services. The UMTRA-Surface RAC, MK-Ferguson Company, is responsible for performing design and surface remedial action. The UMTRA-Groundwater RAC has yet to be determined.

\subsubsection{Technical Assistance Contractor}

The resources and expertise required to accomplish the responsibilities of the TAC are provided by Jacobs Engineering Group Inc., and its subcontractors Roy F. Weston, Inc.; Geraghty \& Miller, Inc.; and Sergent, Hauskins \& Beckwith. The TAC is responsible for development, implementation, and operation of Project-level programs for ES\&H, QA, public participation and information, document control, and cost and schedule control and integration.

The TAC also provides technical support. These activities include: characterizing sites; monitoring radon off of the site; monitoring technology development; coordinating the NEPA review process and preparation of appropriate NEPA compliance documentation; developing remedial action concepts, conceptual designs, remedial action selection reports, and remedial action plans; conducting special studies; addressing all groundwater protection issues and developing groundwater protection strategies; reviewing final designs and providing technical assistance during construction; recommending certification of remedial action and coordinating site licensing; and conducting interim surveillance and monitoring at disposal sites.

The TAC provides technical and management support to both the surface and groundwater portions of the Project through the use of a matrix management structure (Figure 1.6). The TAC organization structure reflects the multidisciplinary nature of its assigned scope of work. 


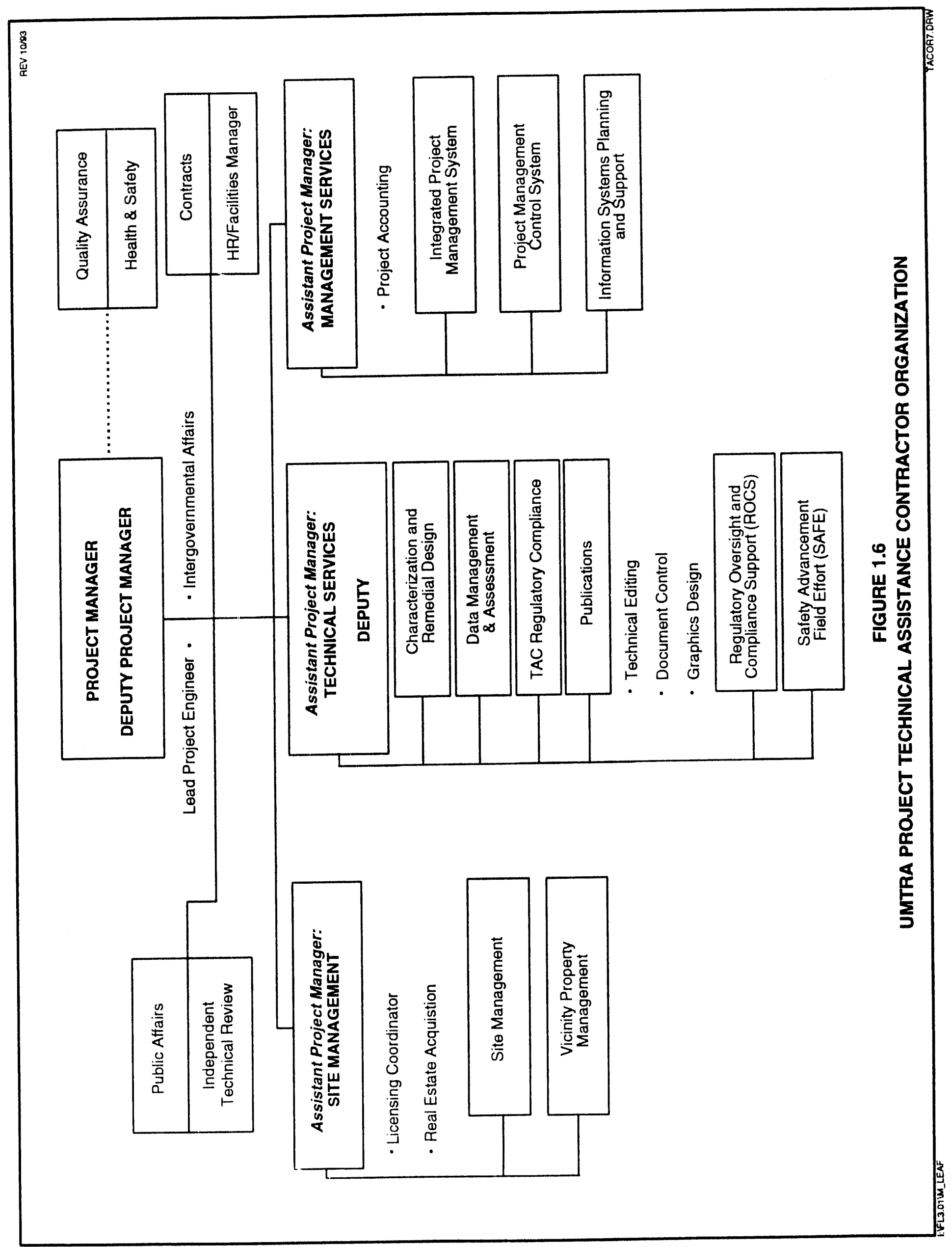




\subsubsection{Remedial Action Contractor}

MK-Ferguson Company is contractually responsible as the RAC for 23 UMTRA Project sites. MK-Ferguson is supported by Chem-Waste Management Federal Environmental Services, inc., which provides technical support for management of the health physics and radiation protection programs, and MK Environmental Services Division, which provides design services, engineering support during construction, environmental permitting support, and completion report support.

The RAC performs overall construction management services in the areas of design, engineering, construction, cost control, procurement, $Q A$, subcontract administration, and ES\&H. The RAC manages these activities in close cooperation and coordination with the DOE, and ensures that end results meet specified and required environmental protection goals.

The RAC's organizational structure is headed by the Project Director and includes all key functions (Figure 1.7). The Project Director provides overall direction to all Project activities and long-range planning.

1.6 HEAD OF FIELD OFFICE RESPONSIBILITIES

DOE Order 5400.1 assigns 13 responsibilities to the heads of field organizations, such as the DOE-AL. This section describes how these responsibilities are fulfilled on the UMTRA Project.

1. Issue and update, as required, a general environmental statement that reflects the statement of policy in this Order and contains broad environmental protection goals for all facilities and activities for which an individual is responsible.

The manager of DOE-AL, Bruce G. Twining, has issued a DOE-AL Environmental Policy Statement (DOE, 1992a). The salient elements of this policy have been incorporated into the UMTRA Project ES\&H plan (DOE, 1992C) and the UMTRA Project ES\&H goal statement (DOE, 1992b). The UMTRA PO oversees contractor activities to ensure compliance with these documents. The UMTRA PO's ES\&H plan and goal statement will be reviewed annually along with the EPIP.

2. Ensure that all operations under their authority comply with applicable environmental protection laws, regulations, and directives.

The UMTRA PO has an ES\&H manager and site managers who are responsible for ensuring that all UMTRA Project operations comply with environmental laws, regulations, and directives. The RAC and the TAC also are responsible for adhering to all environmental laws, regulations, and directives. Compliance is accomplished through the performance of appropriate characterization studies of materials found on UMTRA sites, environmental monitoring, and periodic environmental audits at all UMTRA construction sites. 


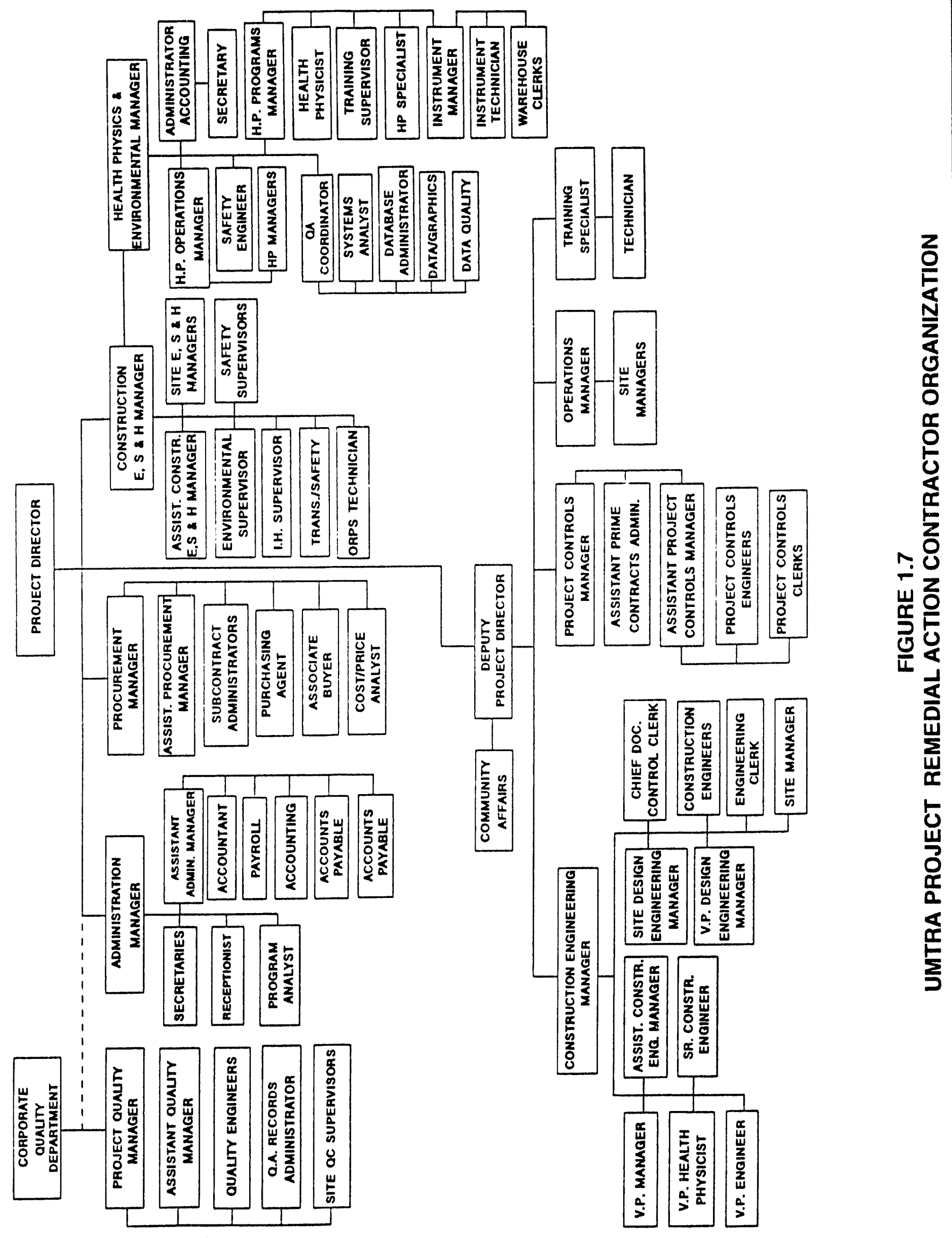


The UMTRA PO is maintaining a regulatory compliance operating envelope data base to document the applicability of and compliance with ES\&H regulations. The Project continually reviews applicable regulations and identifies any steps necessary to ensure complete compliance. Any variances or exceptions will be documented. If complete compliance cannot be achieved technically or is not warranted due to programmatic circumstances, contractors are to prepare an exemption request for UMTRA PO review. If the UMTRA PO determines that an exemption is warranted, the exemption procedure in DOE 5400.1, Chapter 1, shall be followed. When appropriate, the UMTRA PO consults with DOE-HO and DOE-AL concerning regulatory exemptions.

3. Identify significant environmental compliance issues that require resolution and coordination, and advise EH-1 and Headquarters program elements promptly.

UMTRA Project environmental compliance issues were identified during the $1991 \mathrm{EH}-24$ baseline environmental audit and the $1992 \mathrm{EH}-24$

environmental management audit. Resolution of these issues is tracked by the UMTRA PO, and quarterly status reports are sent to DOE-HO.

The UMTRA PO has an ES\&H Committee, which provides support in resolving compliance issues identified by audits, and identifying and resolving future environmental compliance issues facing the Project. The Committee meets monthly and its activities are tracked and reported to Project participants including, if appropriate, DOE-HQ.

4. Ensure that all required environmental permits are secured from the appropriate regulatory agency prompt/y. Consistent with the requirement of DOE Order 5400.2A, in negotiating the terms and conditions of permits, settlements, consent orders, consent decrees, and other legal or administrative documents, every effort shall be made to ensure that permit requirements and conditions reflect the requirements of environmental regulations, are consistent with national security interests, and are costeffective.

The primary responsibility at the UMTRA PO for seeking, obtaining, and implementing environmental clearances, permits, consultations, and approvals during the NEPA compliance phase rests with the TAC. The primary responsibility at the UMTRA PO for seeking, obtaining, and implementing construction and remedial action-related environmental permits rests with the RAC. The UMTRA Project has cooperative working relationships with all of the Federal, state, tribal, and local government offices and regularly reviews compliance requirements. Historically, the Project has had permits in place when required. 
5. Conduct environmental appraisals of programs, projects, and facilities in accordance with DOE Order 5482.1B and other ES\&H requirements, and provide copies of appraisal reports to EH-1 and the appropriate program office.

The UMTRA PO, supported by the TAC, began conducting annual environmental audits of the RAC at UMTRA sites under construction in FY1992. Copies of these audits are kept internal to the UMTRA Project. However, primary responsibility for the environmental appraisal program lies with the DOE-AL Environmental Protection Division, which provides copies of its appraisal reports to EH-1.

6. Establish and maintain liaison and cooperative programs with appropriate Federal, regional, state, and local environmental officials so as to facilitate effective environmental management.

As stated earlier, the UMTRA PO has cooperative working relationships with all participating Federal, regional, state, and local anvironmental officials regarding the UMTRA sites. As required by tine UMTRCA, the DOE has cooperative agreements in place with each state or Indian tribe affected by the Project. Each party's (the state or Indian tribe, and DOE) responsibility for funding, acquisition of the mill tailings site, final design concurrence, and remedial action is defined in the cooperative agreements. The UMTRA Project holds public meetings to solicit public concerns about UMTRA Project activities in their communities. The importance of open communication is stressed to keep all participants abreast of concerns, problems, and resolutions.

7. Develop and implement programs that direct contractors to execute environmental protection compliance programs and policies, and provide for oversight, confirmation, and independent verification of those contractor programs.

The UMTRA ES\&H plan (DOE, 1992C) provides guidance and direction necessary for UMTRA contractors to implement their own ES\&H programs. The plan specifies the basic Federal ES\&H standards and DOE requirements applicable to the program. The UMTRA PO, supported by the TAC, performs annual environmental audits of the RAC at each UMTRA construction site. These are documented and discussed with the RAC and all findings are resolved.

8. Prepare long-range environmental protection plans in accordance with guidance issued by EH-1.

Subsequent DOE-HQ guidance states that the Environmental Restoration and Waste Management Five-Year Plan for the Uranium Mill Tailings Remedial Action Surface Project (DOE, 1993d) satisfies the long-range planning requirements of DOE Order 5400.1. The UMTRA PO submits a five-year plan that is included in DOE-AL's five-year plan. 
9. Ensure that budget requests provide for required environmental protection upgrades and corrective actions, that they are timely, and are consistent with pollution abatement plans prepared as required by OMB Circular A-106.

The UMTRA Project is not required to comply with the requirements of Office of Management and Budget (OMB) Circular A-106. According to DOE-HO guidance on the FY1992 A-106 plan update, DOE field offices are instructed to exclude activities at facilities not owned or leased by the DOE. The UMTRA Project is specifically listed as an example of activities not subject to reporting under OMB Circular A-106.

10. Prepare biannual pollution abatement plans required by OMB Circular A-106 and submit to EH-1 on a schedule provided by that office.

See response to No. 9.

11. Provide EH-1 with all environmental information and documentation that is requested.

The Environmental Frotection Division is the primary DOE-AL contact for environmental information and documentation requested by $\mathrm{EH}-1$. All DOE-HO requests are answered promptly.

12. Curtail or suspend any operation that poses a clear and present danger to a member of the public or to the environment.

Consistent with DOE-AL's Imminent Danger Response Actions policy (DOE, 1991c), the UMTRA PO has a standing policy that any UMTRA PO, RAC, or TAC employee has the authority to suspend operations if a clear and present danger to a worker, a member of the public, or the environment is identified. Stop-work authority on the UMTRA Project is identified in the UMTRA ES\&H plan (DOE, 1992c).

13. Provide for community public information and education programs concerning DOE environmental protection regulations and national security interests.

The UMTRA Project provides a community relations plan and a public information repository at each of the remediation sites throughout the country. These reports contain pertinent facts and information about the UMTRA Project as it relates to that site. The UMTRA Project also allows public participation in decision-making through the NEPA process and is responsive to all inquiries made to the Project. Public meetings are conducted quarterly by the UMTRA PO to inform and actively involve the public on key status items being implemented at all stages of site UMTRA activities. In general, public meetings are held in local government facilities. 


\subsection{RESOURCE AND SCHEDULE SUMMARY}

The schedule and cost estimates contained in Figures 1.8 and 1.9 are planning estimates only. Figures 1.8 and 1.9 give a broad overview of the resources and schedules included in the UMTRA-Surface Project FY1995 program planning level budget from the UMTRA five-year plan (DOE, 1993d). The UMTRA PO projects that the surface project will be completed in FY1998, with remedial action completed 2 years earlier. Estimates for the UMTRA-Groundwater Project are undergoing changes to reflect a new optimization approach to the project. Current estimates for the UMTRA-Groundwater Project are for a completion date in the year 2014 and a total Project cost of $\$ 692$ million. Estimates for both surface and groundwater projects are revised, as necessary, to reflect Project changes. 

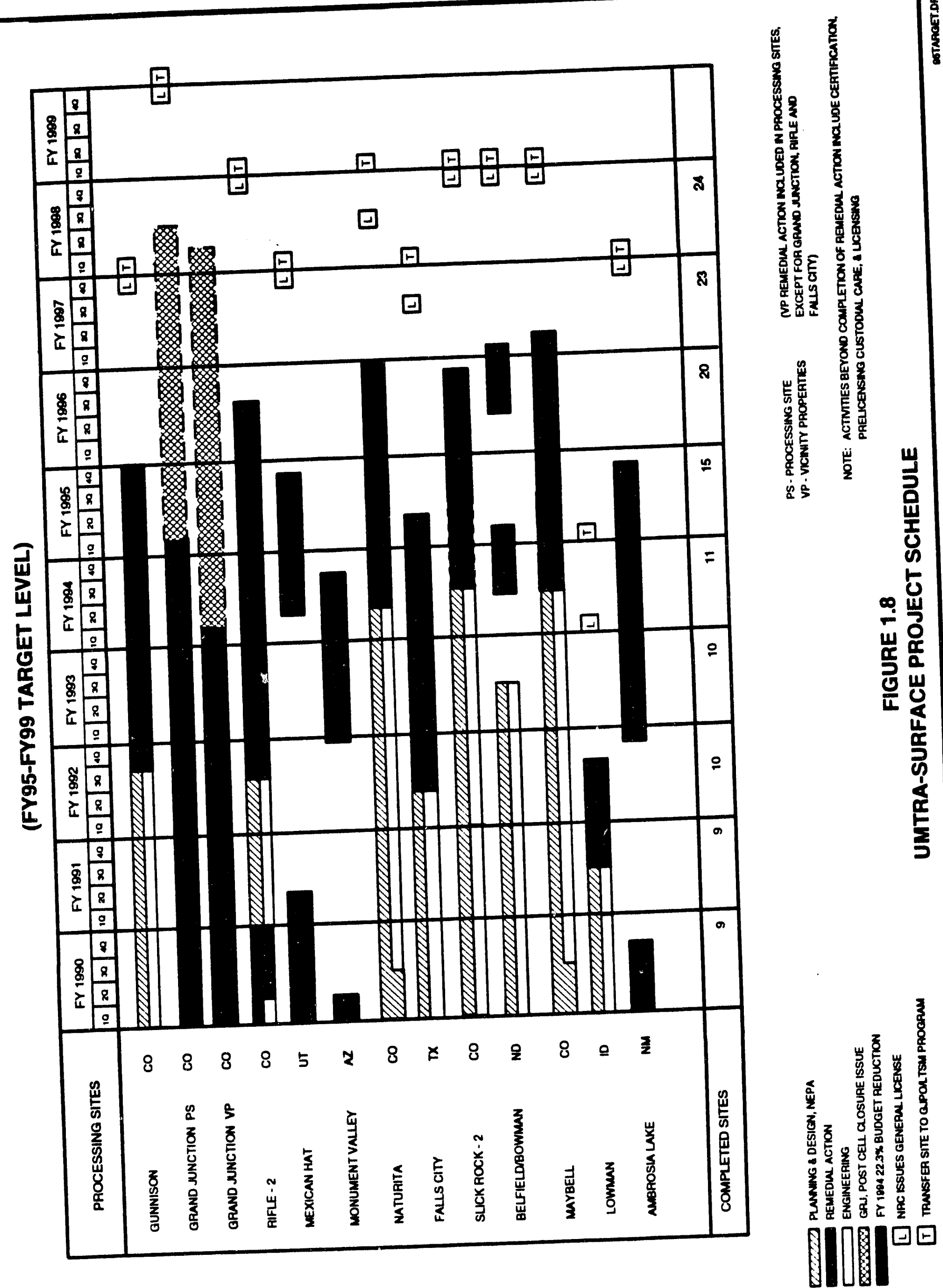


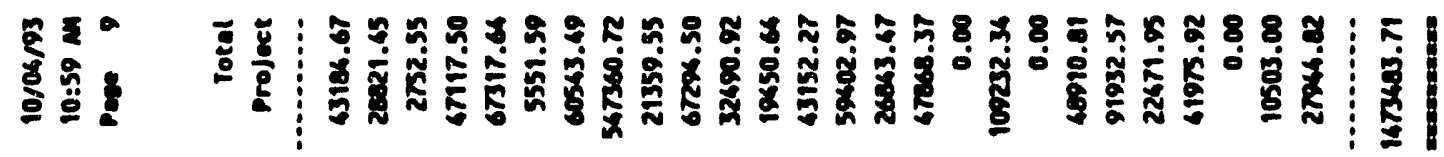

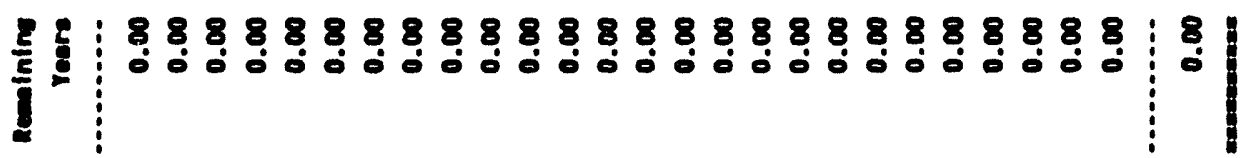

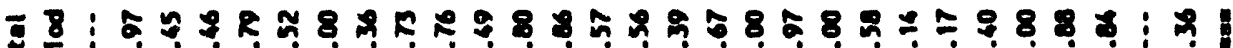

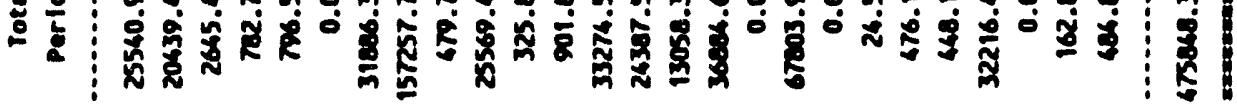

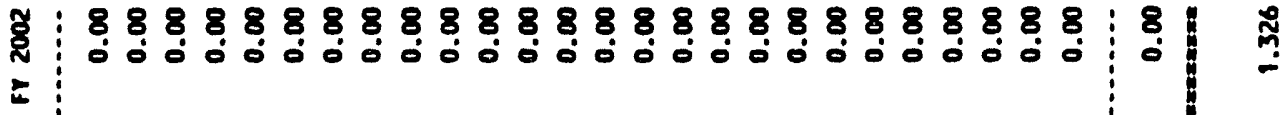

б

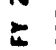

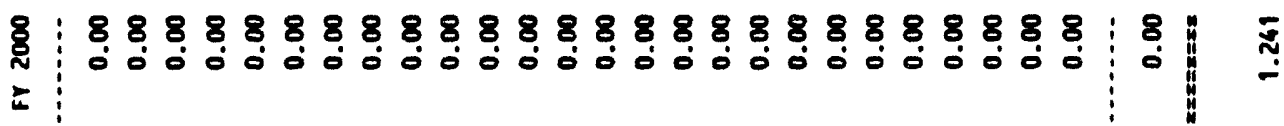

忞

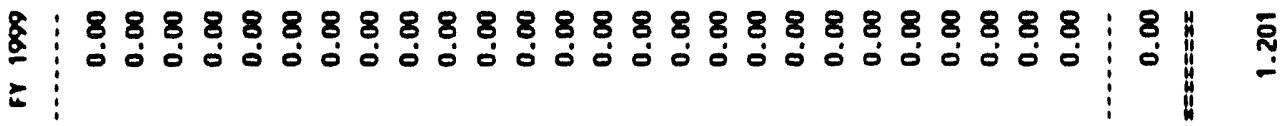

政

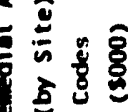

๕

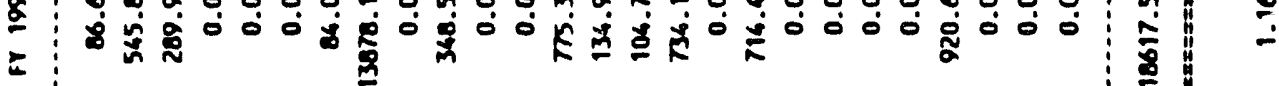

管

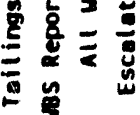

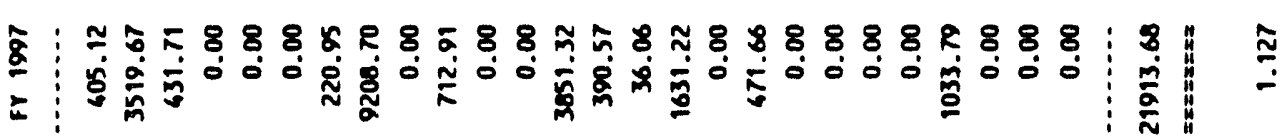

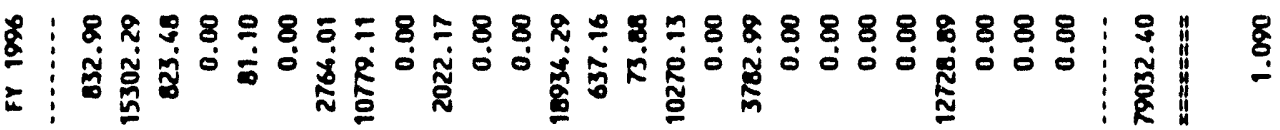

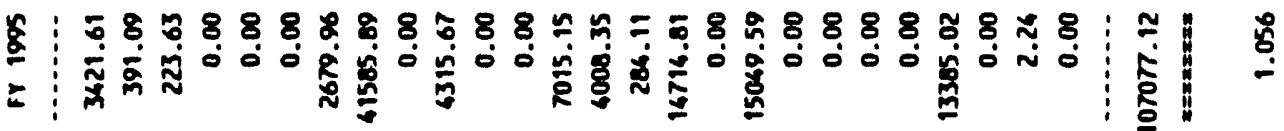

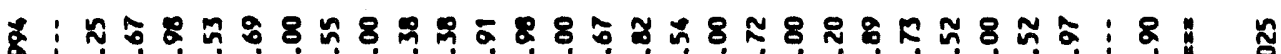

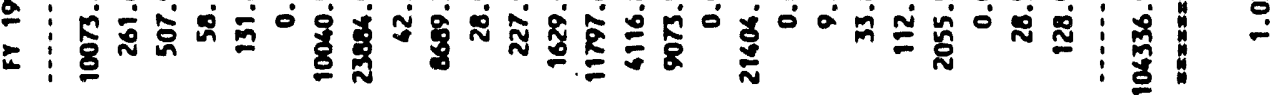

\&

2

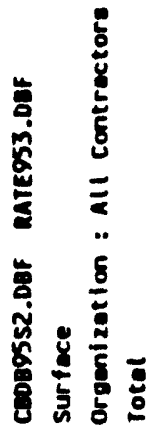

L

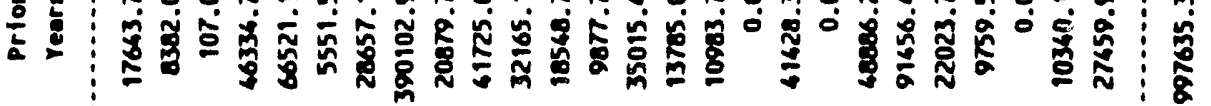

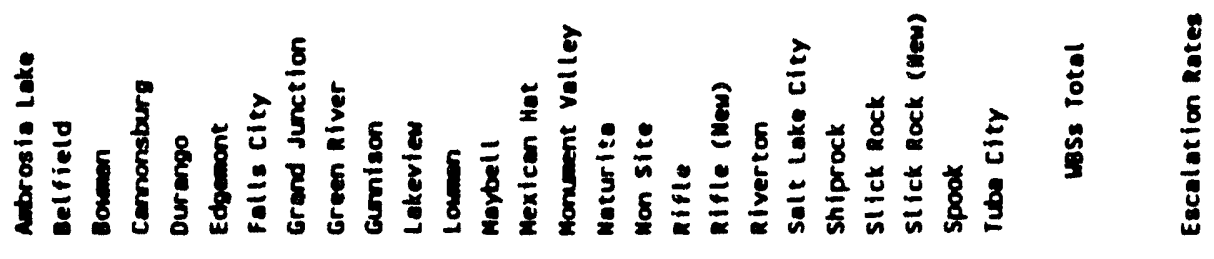




\subsection{NOTIFICATIONS}

Requirements for the reporting of occurrences (emergencies, unusual occurrences, and off-normal occurrences) are specified in DOE Order 5000.3B. The UMTRA Project is considered to be a single facility for the purposes of this Order. An UMTRA Project 5000.3B Program and implementing procedures have been developed to ensure compliance with the Order (DOE, 1993e). In the implementing procedures, the UMTRA Project Manager is identified as the DOE Facility Representative, UMTRA PO line management staff have been identified as DOE Facility Representative Designees, and the UMTRA PO Site Managers have been identified as the Facility Managers for UMTRA sites. Occurrence notification of DOE-HO and DOE-AL are addressed in the program, as well as U.S. Department of Transportation (DOT) notification procedures for spills of hazardous wastes, including notification of the National Response Center, when applicable. The UMTRA PO continues to participate in the Daily Incident and Occurrence Reporting System established by the Office of the Manager, DOE-AL.

The TAC follows the UMTRA PO implementing procedures, as well as TAC-specific procedures, to implement the requirements of the UMTRA PO procedures. The RAC has developed an emergency notification plan to satisfy the requirements of DOE Order 5000.3B. Both the contractors have designated 5000.38 Program Coordinators responsible for maintaining the program.

For all 5000.3B occurrence categories, reporting to the specific UMTRA contractor office is required. The specific contractor office then has the responsibility to report, as appropriate, to the UMTRA PO. Depending on the type of occurrence, the specific contractor office will report to state and Federal agencies having appropriate jurisdiction as delineated in permits and regulatory requirements. Additional reporting requirements are then determined by the UMTRA PO. Reportable environmental incidents are electronically submitted by the UMTRA PO to the DOE data base as required by DOE Order $5000.3 B$.

The RAC and the TAC are required to notify the UMTRA PO in case of a reportable occurrence. These procedures include reports related to radiological releases or spills. Section XI. Emergency Action, in the RAC's Construction Environment, Safety and Health Management Plan (RAC, 1993), covers severe weather, contaminated material spilled in transit, and evacuation from the work site. At each active UMTRA site, a list is posted with emergency telephone numbers and local utility numbers that workers are required to call when necessary.

The RAC developed a procedure to direct the emergency response to transportation accidents involving mill tailings and a health physics emergency response procedure that details the notification requirements for accidents involving radioactive mill tailings. These emergency response procedures are in compliance with the notification requirements of DOT Exemption DOT-E 10594 and applicable portions of 49 CFR Parts 171, 172, and 173. 
The UMTRA PO also complies with reporting requirements for the National Pollutant Discharge Elimination System (NPDES) and the Emergency Planning and Community Rightto-Know Act of 1986 (42 U.S.C. 511001 et seq.) when applicable.

The TAC and the RAC are responsible for preparing an annual site environmental report, that includes a summary of occurrences and exceedances. It is reviewed and distributed through the UMTRA PO (see Section 3.2).

DOE Order 5400.5 states that the public dose limit from exposure to radiation sources from routine DOE operations and activities (including remedial action) is 100 millirem (mrem) annual effective dose equivalent. Additionally, this Order states (to the extent required by the Clean Air ACt, 42 U.S.C. $\$ 7401$ et seq.) that the exposure of members of the public to radioactive materials released to the atmosphere as a consequence of routine DOE activities shall not cause members of the public to receive $10 \mathrm{mrem}$ annual effective dose equivalent.

However, conditions exist, and will continue to occur, during the UMTRA Project remedial activities where the public could be exposed to a dose in excess of $100 \mathrm{mrem}$ per year (Oldham, 1990; Themelis, 1990). The conditions producing radon-222 emanation during remedial action are beyond the RAC's control. However, it is the intent of the UMTRA PO that when remedial action at a site is completed (tailings stabilized), the site will meet applicable requirements of DOE Order 5400.5 . Therefore, the projected doses to the public from remedial action activities (which have been previously calculated in the respective site environmental impact statement or environmental assessment) are not repeated annually. The PO and DOE-AL are working with DOE-HO to resolve the applicability of DOE Order $\mathbf{5 4 0 0 . 5 .}$ 


\subsection{PLANNING AND REPORTING}

This section describes the series of plans and reports that the UMTRA Project is required to prepare to fulfill the requirements of DOE Order 5400.1 as part of its environmental protection program. These requirements include a long-range environmental protection plan, an annual environmental site report, and an OMB Circular A-106 report. The TAC and the RAC are responsible for the preparation of the Project documents, which are subject to review and approval by the UMTRA PO, that satisfy the Order requirements.

\subsection{LONG-RANGE ENVIRONMENTAL PROTECTION PLAN}

The DOE-AL. Environmental Restoration and Waste Management Five-Year Plan satisfies the DOE Orjer 5400.1 requirement for a long-range environmental protection plan. The UMTRA five-year plan provides UMTRA-specific information for inclusion in DOE-AL's five-year plan, including major milestones, funding requirements, Project assessments, history, and activity data sheets for each UMTRA site. The RAC and TAC support the UMTRA PO in the annual preparation of the UMTRA five-year plan.

\subsection{ANNUAL SITE ENVIRONMENTAL REPORT}

The Project is in compliance with the DOE Order 5400.1 requirement for the preparation of an annual site environmental report. The UMTRA PO prepares the UMTRA Project Annual Environmerital Monitoring Report (AEMR), which includes information on all UMTRA sites that have conducted significant environmental remediation programs. Summary reports of the NEPA-related compliance activities performed by the TAC are also included, as are construction-related compliance activities performed by the RAC. The TAC is responsible for performing water quality analysis from the groundwater monitor wells established at each site. These data are also incorporated into the AEMR. The AEMR also serves as a vehicle to report occurrences and exceedances.

All field-gathered environmental data related to remedial action, except Track Etch data, are summarized and presented graphically to assess site environmental management performance. These data are reviewed internally by appropriate RAC and TAC managers and relayed to each site with management's evaluations. Significant trends are investigated and corrective action is taken, as necessary.

The AEMR covering the various activities of the previous calendar year is prepared and distributed each year. Funding for the report is provided through general site and coordination budgets. The UMTRA PO is responsible for approving and distributing the AEMR to DOE-AL, DOE-HO, and the states and tribes. 


\subsection{OMB CIRCULAR A-106}

The UMTRA Project is specifically exempted from compliance with the annual reporting requirements of OMB Circular A-106. According to DOE guidance on the FY1992 A-106 plan update, DOE field offices are instructed to exclude activities at facilities not owned or leased by the DOE. The UMTRA Project is specifically listed as an example of activities not subject to reporting under $O M B$ Circular A-106. 


\subsection{SPECIAL PROGRAMS}

This section describes the special programs the UMTRA Project has developed as part of its environmental protection program to fulfill the requirements of DOE Order 5400.1 for a groundwater protection management program, a waste minimization program, and a pollution prevention awareness program. The UMTRA PO has chosen to incorporate into one planning document both the waste minimization and the pollution prevention awareness programs. The UMTRA Project has also instituted an ES\&H regulatory operating envelope program to document compliance of its environmental programs. The TAC and the RAC are responsible for the preparation of the special program plan documents, subject to review and approval by the UMTRA PO.

\subsection{GROUNDWATER PROTECTION MANAGEMENT PROGRAM}

The UMTRA Project is mandated by UMTRCA to minimize health hazards to the puhlic and the environment. The EPA has proposed groundwater protection standards (EPA, 1987) specifically for the UMTRA Project. In addition, the NRC is responsible for providing regulatory oversight of the UMTRA Project, including the groundwater protection program. Since the UMTRA Project is an environmental remediation project, the primary concerns for groundwater protection arise from the selected remedial action alternatives and from residual contamination after the surface remedial action is complete. Groundwater protection is considered in evaluating remedial action alternatives and general site activities.

The DOE has invested significant resources to address groundwater protection on the UMTRA Project. An integral part of UMTRA includes an experienced staff of hydrogeologists, geochemists, regulatory analysts, engineers, $Q A$ specialists, and data managers who provide a strong technical basis for the development of the surface and groundwater remediation programs. Over the life of the Project, a substantial body of hydrogeologic data has been collected. A large quality-assured computer data base is used to store hydrogeologic data. Also, state-of-the-art computer models are used in conjunction with the hydrogeologic data to develop groundwater protection strategies and assess and remediate risk to the public and the environment.

The UMTRA Project groundwater protection program has been developed and implemented by the TAC and the RAC for the DOE. The UMTRA Project Groundwater Protection Management Program Plan (DOE, 1992d) summarizes the remedial action status of the 24 UMTRA sites. The plan addresses the types of information required to develop a site-specific water resources protection strategy for each site. In addition, the plan identifies and describes available Project technical and site-specific documents which provide guidance for the groundwater protection program.

This plan also describes applicable environmental protection laws, regulations, executive orders, and internal DOE policies that pertain to the preservation and protection of groundwater resources at UMTRA sites. Finally, it highlights the 
Project programs for surface remedial action, long-term surveillance, and groundwater monitoring and restoration activities for the preservation and protection of groundwater resources at each of the sites.

The UMTRA Project Groundwater Protection Management Program Plan (DOE, 1992d) will be revised in FY1994. Subsequently this plan will be reviewed annually and updated every 3 years.

\subsection{WASTE MINIMIZATION/POLLUTION PREVENTION AWARENESS PROGRAM}

The UMTRA Project is mandated to remediate designated inactive uranium tailings sites and their associated wastes by consolidating and stabilizing the RRM in geotechnically suitable impoundments. As an environmental restoration program, the Project does not have manufacturing or production facilities, nor does it routinely generate new hazardous waste streams.

A combined Waste Minimization/Pollution Prevention Awareness Program (WM/PPAP) plan, for both office/administrative locations and construction and site activities, has been developed and was implemented in FY1992 (RAC. 1992a). The WM/PPAP plan will be revised in FY1994. Subsequently, it will be reviewed annually and updated every 3 years.

The WMIPPAP plan is intended to satisfy DOE requirements for the management of radioactive and hazardous wastes mandated by DOE Orders $5400.1,5400.3$, and 5820.2A. As stated above, long-term volume-specific comprehensive goals for waste minimization, such as those specified by the Resource Conservation and Recovery Act, are not appropriate for nonoperational facilities such as the UMTRA Project. It is more appropriate to adopt as an overall goal the as low as reasonably achievable (ALARA) concept routinely associated with personnel exposures.

The WM/PPAP plan addresses UMTRA Project requirements for source reduction, minimization, and pollution abatement. It serves as a guidance document for current and future waste minimization and pollution prevention activities by specifying responsibilities, goals, and key elements of the joint program. These goals include:

1. Eliminate the generation of hazardous waste.

2. Reduce the generation of radioactive waste to ALARA.

3. Reduce the generation of nonhazardous solid waste to ALARA.

4. Use the ES\&H Committee to address waste minimization and pollution prevention issues, as needed.

5. Provide guidance for management and worker awareness in waste minimization and pollution prevention. 
6. Provide guidance for the development of site-specific plans that implement waste minimization and pollution prevention practices.

Waste minimization involves activities that will eliminate or minimize the generation of radioactive, hazardous, and other solid wastes. For the UMTRA Project, waste minimization begins with the development and implementation of subcontract specifications and the RAC construction ES\&H plan (RAC, 1993). These documents outline specific waste minimization requirements that must be developed by subcontractors and approved by Project management.

During the startup of construction activities at new sites, or during recent construction at active sites, site-specific plans are developed plan detail the necessary waste management activities to ensure that all elements of the WM/PPAP plen are implemented, including:

1. Identification of site-specific wastes and waste streams.

2. Development of contingency plans for potential leaks and spills.

3. Development of contamination prevention procedures for equipment and materials.

4. Review of waste handling and disposal methods.

5. Evaluation of waste reuse and recycling options.

6. Quality assurance.

7. Waste tracking and record keeping.

\subsection{ES\&H OPERATING ENVELOPE PROGRAM}

The UMTRA PO has established an ES\&H regulatory operating envelope program to identify all environmental regulations applicable to the UMTRA Project and determine the level of compliance. This program is consistent with the Standards/Requirements Program being developed by DOE-HO and will improve the UMTRA PO's ability to assess its environmental programs.

The Project has created a regulatory operating envelope data base, identified the applicable regulatory documents, and developed justifications for nonapplicable regulations. The UMTRA PO also has developed a plan to implement the next stage of the program, which involves determining the applicability of individual regulatory criteria, assessing compliance, and identifying actions necessary to attain compliance (DOE, 1993f). This plan describes the Projects' systematic approach for defining its regulatory operating envelope and documenting its compliance status. The TAC is responsible for implementing the program and maintaining the operating envelope data base. 


\subsection{ENVIRONMENTAL MONITORING PROGRAMS}

\subsection{ENVIRONMENTAL MONITORING PLANS}

The UMTRA Project Environmental Monitoring Plan (EMP) defines responsibilities and provides guidance on the format and content of the various subtier environmental monitoring plans for the UMTRA Project sites (DOE, 1992e). The EMP includes a description of all Project environmental monitoring programs. The relation of the EMP and its subtier plans to the environmental protection program is shown in Figure 1.3. The EMP contains the requirements for the environmental monitoring program concerning 1) the measurement and monitoring of effluents, and 2) surveillance through the measurement, monitoring, and calculation of the effects of the Project's operations on the environment and public health. The objectives of the program are to demonstrate compliance to applicable regulations, confirm adherence to DOE environmental policies, and support environmental management decisions. A critical element of the monitoring program is $O A$ and data verification.

Environmental monitoring for groundwater and radon, the areas of primary focus of the UMTRA environmental monitoring program, are also described in the Guidance for Implementing the UMTRA Project Long-Term Surveillance Program (DOE, 1992f), the "Groundwater Monitoring Plan" (an attachment to the EMP) and the Outdoor Radon Monitoring Plan for the UMTRA Project Sites (DOE, 1990). Groundwater and radon data collection, analyses, and storage are specified in the documents cited in Section 4.1, and in those referenced in Section 5.2. $Q A$ and data verification procedures and requirements are discussed in the UMTRA Project Quality Assurance Program Plan (QAPP) (DOE, $1992 \mathrm{gl}$.

\subsection{ENVIRONMENTAL MONITORING ACTIVITIES}

The project monitoring program is divided into two general categories: 1) environmental surveillance, and 2) effluent monitoring. Radiological surveillance is conducted at Project sites to ensure that radionuclide releases are within the limits of DOE Order 5400.5, with the exception of radon gas levels, before and during construction activities. Radon releases are beyond the control of the Project. Monitoring is performed in air for radon and radioactive particulates, in surface water for dissolved and suspended radionuclides, and for direct gamma radiation. These measurements are compared to background levels established during pre-remedial action surveys and to applicable regulatory limits.

Environmental surveillance is conducted for nonradiological pollutants, including measuring total suspended particulates in air at all Colorado sites, and monitoring discharge of water as required by the Clean Water Act at all sites. Groundwater monitoring is conducted at all sites prior to remedial action to characterize hydrological and contaminant conditions. It is monitored during 
remedial action to determine the remedial action effects, and after remedial action where necessary to demonstrate compliance with the proposed EPA groundwater protection standards.

The TAC conducts pre-remedial action monitoring and characterization for groundwater and radon. The Outdoor Radon Monitoring Plan for the UMTRA Project Sites (DOE, 1990) details radon measurement techniques and monitoring requirements during all phases of remediation. Groundwater monitoring is conducted in accordance with the "Groundwater Monitoring Plan" attachment to the EMP. Initial site-specific monitoring requirements are developed based on preoperational site characterization. Water sampling and analysis plans are prepared for each site and revised annually based on reviews of groundwater quality data.

Ambient air quality monitoring is performed by the RAC during construction as required by the applicable Federal, state, or local air quality permits. Ambient air quality monitoring at the UMTRA sites ranges from estimating fugitive dust levels using opacity criteria, to measuring total suspended particulates as required by 40 CFR Part 50 and as detailed in the EMP. The aspects of the program coordinated with state regulatory officials include siting monitoring stations, developing monitoring protocols, conducting audits, acquiring meteorological information, and evaluating current site and background data.

Either an NPDES permit or the equivalent state permit is obtained before remedial action starts at each UMTRA site. Data gathered for the site-specific NEPA document and remedial action plan are used to provide the water quantity and quality data required to complete the water use and discharge permit application. In general, shallow groundwater data are used to estimate the quality of the water to be collected. Historical meteorological data are used to determine the quantity of water that may accumulate at the site. If it appears that there will be a net positive accumulation of water, an appropriate water treatment and discharge plan is required.

The permits will specify site-specific limitations on both the volume and contaminant levels in water to be discharged. In addition, the permit will state the frequency with which these measurements are to be made and the form in which they must be reported.

RAC site engineering personnel are assigned the task of collecting the data required by the individual permit and reporting it to the governing authority. The RAC site engineering, safety, and industrial hygiene personnel are assigned the responsibility of ensuring that all permit requirements are completed.

Attachment A briefly describes the environmental monitoring at sites with ongoing surface remedial action activities.

The estimated annual cost of UMTRA Project environmental monitoring activities at all UMTRA sites is $\$ 1.7$ million. 


\subsection{QUALITY ASSURANCE AND DATA VERIFICATION}

6.1

\section{QUALITY ASSURANCE PROGRAM}

The UMTRA Project QA program is currently consistent with DOE Order $5700.6 \mathrm{C}$ and covers the applicable portions of the 11 elements described in DOE Order 5400.1. The TAC's QAPP (TAC, 1992) uses the Project QAPP for guidance and instruction in $Q A$ and quality control activities. A statement of policy regarding the RAC's QAPP (RAC, 1992b) has been provided to DOE. Both the RAC and the TAC revised their QAPPs in FY1992 to conform with DOE Order 5700.6C. The UMTRA PO is currently preparing a separate plan for implementing the UMTRA-Groundwater Project QA program.

In addition, independent data verification is performed by the TAC and RAC. The TAC, in conjunction with the UMTRA PO, performs QA in-process surveillances, environmental audits, and radiological surveillances at least annually at all operating UMTRA sites. Prequalification QA audits are conducted prior to awarding subcontracts to analytical laboratories. Thereafter, annual $Q A$ audits are conducted to verify compliance with subcontract technical and $Q A$ requirements. All environmental data, methodology of collection, and analyses performed are reviewed for adequacy, accuracy, and completeness. Reports are then generated requiring RAC response, as necessary, for audits and surveillances conducted at UMTRA sites during remedial action. Reports of QA audits of subcontract laboratories are generated and may also require a written response and corrective action. Periodic audits and surveillance are conducted as the Project progresses. The RAC has established an environmental assessment program in conjunction with the quality audit program referenced in the RAC QAPP.

\subsection{LABORATORY CERTIFICATION}

The laboratories in Table 6.1 have been or are currently used by the TAC and the RAC for environmental analyses. Some changes to this list are expected during FY1994.

The radiological analyses laboratories used by the RAC and TAC participate in the EPA's Environmental Monitoring Systems Laboratory Las Vegas Intercomparison Studies Program, as required by DOE Order 5400.1. Participation in this program is also required by the state of Colorado. Quarterly summaries of their Intercomparison Studies performance are sent by the laboratories to the RAC and TAC for review by data management and QA staff.

In addition to the above, independent quarterly performance evaluation samples are sent by the TAC to the participating laboratories. These samples are prepared for the UMTRA Project by RUST Geotech and cover constituents of interest to the UMTRA Project. 
Table 6.1 UMTRA Project contract laboratories

\begin{tabular}{|c|c|c|}
\hline Laboratory & TAC & RAC \\
\hline Accu-Labs Research & -- & $x$ \\
\hline ACZ Laboratories, Inc. & $x$ & -. \\
\hline Barringer Laboratories, Inc. & $x$ & $x$ \\
\hline CDS Laboratories & -. & $x$ \\
\hline RUST Geotech & $x$ & $x$ \\
\hline Core Laboratories, Inc. & $x$ & $\because$ \\
\hline Environmental Science and Engineering, Inc. & $x$ & -- \\
\hline Data Chem Laboratories, Inc. & -- & $x$ \\
\hline Pace Incorporated & - & $x$ \\
\hline Tech/Ops Landauer, Inc. & -- & $x$ \\
\hline IT Analytical Services & $x$ & -- \\
\hline TMA/Eberline Analytical, Inc. & -. & $x$ \\
\hline Weyerhauser Laboratories, Inc. & $x$ & -- \\
\hline R. F. Weston Analytical Laboratory & $x$ & -- \\
\hline IEA Laboratory & $x$ & -- \\
\hline Savannah Laboratories & $x$ &.- \\
\hline Lockheed Analytical Laboratory & $x$ &.$\cdot$ \\
\hline
\end{tabular}

Tech/Ops Landauer, Inc., which is used for radon monitoring services, participates in DOE's Technical Measurement Center Program.

CDS Laboratories, which is the primary vendor for total suspended particulate analysis, participates in the EPA Interlaboratory Correlation Total Suspended Particulate Audit Program.

In addition to the QA program mentioned above, the RAC and TAC periodically ship blank samples to the laboratories for analyses as a quality control check of the data, and to ensure that the required monitoring sensitivities are being achieved. The RAC and TAC also perform initial and periodic follow-up audits of analytical laboratories.

These QA checks of analytical laboratories have been determined to be adequate and appropriate for UMTRA Project environmental analyses.

\subsection{DOE LABORATORY QA PROGRAM FOR RADIOACTIVE MATERIAL}

UMTRA Project sites have on-site laboratories to analyze soil samples for radium-226 (Ra-226) activity concentration and airborne particulates for gross 
alpha activity concentration. The RAC measures the Ra-226 activity concentration in soil samples with an opposed sodium iodide crystal system. The system is calibrated with Ra-226 standards obtained from DOE's Technical Measurement Center in Grand Junction, Colorado.

The TAC provides blind soil samples (spiked with Ra-226) to the RAC for Ra-226 analysis. These blind soil samples are used by the TAC to test sample result accuracy, quality control, and chain-of-custody. The RAC's blind test results must meet test criteria presented in the UMTRA Project Technical Approach Document (DOE, 1989).

The UMTRA Project does not participate in the DOE Laboratory Quality Assurance Program because the program's test matrices predominantly contain fission products and transuranium elements, while the UMTRA Project's focus is on naturally occurring radioactivity and radionuclides.

\subsection{INDEPENDENT DATA VERIFICATION}

The DOE QA manager has the responsibility for overseeing development of the Independent Data Verification Program. The present data collection, analysis, and review programs now in place meet the requirements and intent of the data verification section of DOE Order 5400.1. Environmental data verification is discussed in the EMP (DOE, 1992f). 


\subsection{REFERENCES}

DOE (U.S. Department of Energy), 19938. GJPO Environmental Protection Implementation Plan, DOE Grand Junction Projects Office, Grand Junction, Colorado.

DOE (U.S. Department of Energy), 1993b. Environmental Management Audit: Uranium Mill Tailings Remedial Action Project, DOE Office of Environmental Audit, Washington, D.C.

DOE (U.S. Department of Energy), 1993c. Uranium Mill Tailings Remedial Action Project Environmental Line Management Audit Action Plan, DOE UMTRA Project Office, Albuquerque, New Mexico.

DOE (U.S. Department of Energy), 1993d. Environmental Restoration and Waste Management Five-Year Plan for the Uranium Mill Tailings Remedial Action Surface Project, DOE UMTRA Project Office, Albuquerque, New Mexico.

DOE (U.S. Department of Energy), 1993e. UMTRA Project Implementing Procedures for DOE Order 5000.3B, Occurrence Reporting and Processing of Operations Information, LDE UMTRA Project Office, Albuquerque, New Mexico.

DOE (U.S. Department of Energy), 1993f. Environmental, Safety, and Health Regulatory Implementation Plan, DOE/AL/62350-44, DOE UMTRA Project Office, Albuquerque, New Mexico.

DOE (U.S. Department of Energy), 1992a. "Albuquerque Operations Office Environmental Policy Statement," October 28, 1992, DOE Albuquerque Operations Office, Albuquerque, New Mexico.

DOE (U.S. Department of Energy), 1992b. UMTRA Project Environmental, Safety, and Health Goal Statement, May 1992, DOE UMTRA Project Office, Albuquerque, New Mexico.

DOE (U.S. Department of Energy), 1992c. UMTRA Project Environmental, Safety, and Health Plan, UMTRA-DOE/AL-150224.0006, DOE UMTRA Project Office, Albuquerque, New Mexico.

DOE (U.S. Department of Energy), 1992d. Groundwater Protection Management Program Plan, UMTRA-DOE/AL-400327.0000, DOE UMTRA Project Office, Albuquerque, New Mexico.

DOE (U.S. Department of Energy), 1992e. UMTRA Project Environmental Monitoring Plan, prepared by MK-Ferguson, CWM Federal Environmental Services, Inc., and Jacobs Engineering Inc., Albuquerque, New Mexico, for the DOE UMTRA Project Office, Albuquerque, New Mexico. 
DOE (U.S. Department of Energy), 1992f. Guidance for Implementing the UMTRA Project Long-Term Surveillance Program, UMTRA-DOE/AL-350124.0001 Rev. A, DOE UMTRA Project Office, Albuquerque, New Mexico.

DOE (U.S. Department of Energy), 1992g. UMTRA Project Quality Assurance Program Plan, UMTRA-DOE/AL-400324.0185, DOE UMTRA Project Office, Albuquerque, Now Mexico.

DOE (U.S. Department of Energy), 1991a. Environmental Audit: Rifle, Gunnison and Grand Junction UMTRA Project Sites, DOE Office of Environmental Audit, Washington, D.C.

DOE (U.S. Department of Energy), 1991b. Final Action Plan in Response to the Environmental Audit of the Uranium Mill Tailings Remedial Action Project at the Grand Junction, Gunnison, and Rifle, Colorado, Sites, DOE UMTRA Project Office, Albuquerque, New Mexico.

DOE (U.S. Department of Energy), 1991 c. DOE Albuquerque Operations Imminent Danger Response Actions, Announcement OOM No. 47, September 19, 1991, DOE Albuquerque Operations Office, Albuquerque, New Mexico.

DOE (U.S. Department of Energy), 1990. Outdoor Radon Monitoring Plan for the UMTRA Project Sites, UMTRA-DOE/AL-150225.0000, DOE UMTRA Project Office, Albuquerque, New Mexico.

DOE (U.S. Department of Energy), 1989. Technical Approach Document, UMTRA-DOE/AL-050425.0002, DOE UMTRA Project Office, Albuquerque, New Mexico.

EPA (U.S. Environmental Protection Agency), 1987. "Proposed Standards for Inactive Uranium Processing Sites with Groundwater Contamination," 52 Federal Register 36000, September 24, 1987, 40 CFR Part 192.

Oldham, J. G., 1990. Project Director, MK-Ferguson Company, letter 90-3050-236 to M. L. Matthews, Project Manager, U.S. Department of Energy, UMTRA Project, dated April 2, 1990.

RAC (Remedial Action Contractor), 1993. MK-Ferguson Company - Construction Environment, Safety and Health Management Plan, MKF-UMTRA-4, prepared by the RAC, Albuquerque, New Mexico, for the U.S. Department of Energy, UMTRA Project Office, Albuquerque, New Mexico.

RAC (Remedial Action Contractor), 1992a. Waste Minimization and Pollution Prevention Program for the UMTRA Project, prepared by the RAC, Albuquerque, New Mexico, for the U.S. Department of Energy, UMTRA Project Office, Albuquerque, New Mexico. 
RAC (Remedial Action Contractor), 1992b. Quality Assurance Program Plan, MK-FUMTRA-5, prepared by the RAC, Albuquerque, New Mexico, for the U.S. Department of Energy, UMTRA Project Office, Albuquerque, New Mexico.

TAC (Technical Assistance Contróctor), 1992. UMTRA TAC Quality Assurance Program Plan, prepared by TAC, Albuquerque, New Mexico, for the U.S. Department of Energy, UMTRA Project Office, Albuquerque, New Mexico.

Themelis, J. G., 1990. U.S. Department of Energy, letter to J. E. Dickhoner, U.S. Department of Energy (EH-32), dated May 16, 1990.

\section{CODE OF FEDERAL REGULATIONS}

10 CFR 40, "Domestic Licensing of Source Material," Title 10, Code of Federal Regulations, Part 40, U.S. Nuclear Regulatory Commission, Office of the Federal Register National Archives and Records Administration, Washington, D.C.

10 CFR 1021, "Compliance with the National Environmental Policy Act," Title 10, Code of Federal Regulations, Part 1021, U.S. Department of Energy, Office of the Federal Register National Archives and Records Administration, Washington, D.C.

40 CFR 50, "National Primary and Secondary Ambient Air Quality Standards," Title 40, Code of Federal Regulations, Part 50, U.S. Environmental Protection Agency, Office of the Federal Register, National Archives and Records Administration, Washington, D.C.

40 CFR 192, "Health and Environmental Protection Standards for Uranium and Thorium Mill Tailings," Title 40, Code of Federal Regulations, Part 192, U.S. Environmental Protection Agency, Office of the Federal Register National Archives and Records Administration, Washington, D.C.

49 CFR 171, "Hazardous Material Information, Regulations, and Definitions," Title 49, Code of Federal Regulations, Part 171, U.S. Department of Transportation. Office of the Federal Register National Archives and Records Administration. Washington, D.C.

49 CFR 172, "Hazardous Material Tables and Communications Regulations," Title 49, Code of Federal Regulations, Part 172, U.S. Department of Transportation. Office of the Federal Register National Archives and Records Administration, Washington, D.C.

49 CFR 173, "Hazardous Material Shippers General Requirements," Title 49, Code of Federal Regulations, Part 173, U.S. Department of Transportation, Office of the Federal Register National Archives and Records Administration, Washington. D.C. 


\section{DOE ORDERS}

Order 5000.38, Occurrence Reporting and Processing of Operations Information, January 19, 1993, U.S. Department of Energy, Washington, D.C.

Order 5400.1, General Environmental Protection Program, November 8, 1988, U.S.

Department of Energy, Washington, D.C.

Order 5400.2A, Environmental Compliance Issue Coordination, January 1989, U.S.

Department of Energy, Washington, D.C.

Order 5400.3, Hazardous and Radioactive Mixed Waste Program, February 1989, U.S. Department of Energy, Washington, D.C.

Order 5400.5, Radiation Protection of the Public and the Environment, February 1990. U.S. Department of Energy, Washington, D.C.

Order 5482.1B, Environmental, Safety and Health Appraisal Program, September 1986. U.S. Department of Energy, Washington, D.C.

Order 5700.6C, Quality Assurance, August 21, 1991, U.S. Department of Energy, Washington, D.C.

Order 5820.2A, Radioactive Waste Management, September 26, 1988, U.S. Department of Energy, Washington, D.C. 
ATTACHMENT A

ENVIRONMENTAL PROTECTION AT SURFACE REMEDIAL ACTIONS SITES 


\section{ATTACHMENT A}

\section{Environmental Protection at Surface Remedial Action Sites}

Of the 24 designated Uranium Mill Tailings Remedial Action (UMTRA) sites, surface remedial action is underway at only 8 sites at the beginning of fiscal year 1994: Ambrosia Lake, New Mexico; Falls City, Texas; Grand Junction, Colorado; Gunnison, Colorado; Mexican Hat, Utah; Monument Valley, Arizona; and two sites at Rifle, Colorado. The environmental protection programs at these sites comply with all applicable state and Federal environmental regulations. Remedial action activities have been evaluated for environmental impact and to ensure that they meet all regulatory requirements. General environmental protection activities include monitoring and discharge of liquid effluents (including storm waters) to surface waters, monitoring of air emissions, and proper storage, disposal, and reporting of hazardous materials used at the sites.

Environmental monitoring at sites undergoing surface remedial action consists of airborne radionuclide monitoring, external penetrating gamma radiation monitoring, fugitive dust monitoring, and ground and surface water monitoring. Internal and external compliance assessments are routinely performed of these activities. Complete training and awareness for management of environmentally hazardous materials is provided to Project managers. supervisors, and selected technical staff. Waste minimization and material recycling occurs when feasible.

In accordance with the U.S. Department of Energy (DOE) policy, UMTRA sites are required to comply with Federal and state environmental requirements. Accordingly, the sites comply with regulations implementing the Clean Water ACt, the Clean Air Act, the Resource Conservation and Recovery Act, and the Emergency Planning and Community Right-To-Know ACt (EPCRA), as well as DOE Orders. Where applicable, site-specific permits are obtained from the appropriate regulatory agencies.

A. Chemical Storage and Waste Management Programs

1. Emergency Planning and Community Right-To-Know

All sites comply with EPCRA requirements by having developed a site inventory for all materials stored on the site in excess of 4540 kilograms $(10,000$ pounds) or in excess of the threshold planning quantities for extremely hazardous materials. The inventories (which include diesel fuel, oil, sulfuric acid, other automotive maintenance fluids, and uranium mill tailings), are submitted to the state emergency response commission, the local emergency planning committee, and the local fire department for each site. All sites comply with the EPCRA requirements by having developed and submitted Tier II reporting forms.

2. Waste Minimization/Recycling

All chemical products used on the site are either consumed in the remediation process, reused, or recycled to ensure overall waste minimization. Local 
qualified vendors are contracted to recycle most of the bulk products, such as oil, fuels, anti-freeze, greases, batteries, etc., on a scheduled basis. Other products, such as spray paint, are not discarded unless their containers are empty. Site surveillence ensures that waste minimization and recycling activities aro implemented.

B. Air Quality Programs

1. Non-Radiological Monitoring

National Emissions Standards for Hazardous Air Pollutants (NESHAP) compliance is maintained for asbestos emissions during excavation when underground pipes containing asbestos insulation are discovered. The state where the site is located issues an asbestos air quality permit prior to abatement. Strict dust control, continuous monitoring, and proper asbestos work practices are implemented during abatement. Site-specific permits/plans covering asbestos management include Ambrosia Lake asbestos removal permits for notification (L0902017) and asbestos management (T0102021), and the Grand Junction Asbestos Disposal Plan (GRJ130).

The Grand Junction, Rifle, and Gunnison sites comply with the Colorado total suspended particulates (TSP) monitoring requirements for fugitive dust. Tho state of Colorado has adopted the Federal TSP lovels. Three TSP monitoring stations are located at both the Rifle and Grand Junction sites, and two TSP monitoring stations are located at the Gunnison site. TSPs are operated under approved protocols which meet Colorado requirements. The TSP monitoring occurs every 3 days at the Rifle site and occurs every 6 days at the Grand Junction and Gunnison sites. Quarterly reports are submitted to the Colorado Department of Health (CDH).

Site-specific air quality permits issued by the $\mathrm{CDH}$ include Grand Junction air permits for the processing (88ME250) and disposal (88ME247) sites, Gunnison air permits for the processing (90GU472F-1) and disposal (90GU472F-2) sites, and Rifle air permits for the processing (88GA191) and disposal (88GA 190) sites.

The Ambrosia Lake site complies with the state of New Mexico's requirements for fugitive dusts. New Mexico requires that fugitive dusts be controlled through dust suppression water sprays as needed. The site has a fugitive dust plan for these activities. There is no permit required.

The state of Texas Air Quality Control Board has regulatory authority over fugitive dust and other air quality standards at the Falls City site. The Falls City site is not required to monitor fugitive dust emissions; however, the site has a fugitive dust plan that restricts off-site transport of fugitive dust.

There is no permit required. 
The U.S. Environmental Protection Agency (EPA) determined that the Mexican Hat and Monument Valley sites, which are on the Navajo Reservation, are not major sources as defined under the prevention of significant deterioration regulations. The major pollutant is fugitive emissions from non-point sources; therefore, the sites do not require permits from the EPA. However, off-site visible fugitive dust emissions are strictly controlled, as required by the Navajo Nation Environmental Protection Department under Air Quality Notice L-09.01500.

2. Radiological Monitoring

Environmental monitoring is also conducted at all sites for airborne radionuclides and external penetrating gamma radiation. Continuous airborne particulate sampling stations have been established at locations adjacent to the sites and in nearby residential areas. Airborne particulate samples are analyzed for gross alphe, radium-226 (Ra-226), and thorium-230 (Th-230). Radioactive redon gas monitoring is conducted continuously at some of the same locations airborne particulates are sampled. External penetrating gamma radiation monitoring is performed continuously at locations adjacent to the sites and in nearby residential areas using thermoluminescence dosimeters.

\section{Water Quality Programs}

\section{Surface Water Discharges}

At all UMTRA sites, surface water runoff/runon is controlled by the use of contoured drainage ditches. These ditches route storm waters to fully lined retention basins. Little of the water collected in these basins is ever discharged. Instead, the collected water is usually allowed to evaporate or is used on the site as construction water.

The Ambrosia Lake site has National Pollutant Discharge Elimination System (NPDES) permit NMO029742, which is a no discharge permit. However, discharges which may occur are covered under a Groundwater Discharge Plan, No. 513, issued by the state of New Mexico. Issuance of a storm water permit for Ambrosit Lake by the state is pending.

The Mexican Hat site is operating under NPDES permit UTO024945 issued by the EPA. Storm water permit applications for this site and Monument Valley have been submitted to the EPA.

The Falls City site has a state of Texas wastewater discharge permit, No. 03382 , for the retention basin. Two storm water permits have been obtained from the state for industrial (TXROOB 708 ) and construction (TXR10F397) activities. 
The Grand Junction site has two Colorado Discharge Permit System (CDPS) permits for the discharge of surface waters generated during site remedial action: a disposal site permit (C00042391) and a processing site permit (CO0042536). Due to discharge treatment problems involving ammonia levels that exceeded permit allowances, the site obtained a pretreatment permit ( $\$ 017)$ from the city of Grand Junction for the routine discharge of site water into the city treatment system.

CDPS permits also have been issued for releases from the Gunnison and Rifle sites. Rifle has discharge permits for both processing sites (CO0042552) and the disposal site (CO0042757). Gunnison has discharge permits for the processing site (CO0042889) and the disposal site (CO0043401).

\section{Spill Prevention Control and Countermeasures Plans}

The Ambrosia Lake site Spill Prevention Control and Countermeasures (SPCC) Plan addresses requirements for spill response, reporting, and secondary spill containment systems for bulk chemical storage areas. Earthen berms around existing above-ground storage tanks and around oil drum storage areas were designed and constructed for the Ambrosia Lake site. These secondary containment systems are designed to provide adequate capacity to control spills.

The Falls City site SPCC plan addresses requirements for spill response, reporting, and secondary spill containment systems for bulk chemical storage areas.

The Grand Junction SPCC plan addresses requirements for spill response, reporting, and secondary spill containment systems for bulk chemical storage areas. Prior to 1990, the Grand Junction site had designed and constructed earthen berms around existing above-ground storage tanks and around drum storage areas. These secondary containment systems are designed to provide adequate capacity to control spills. In addition, SPCC plans for inspecting berms, detecting spills, emergency spill response, and spill cleanup were developed for fuel, oil, and other storage areas.

The Gunnison site implemented an SPCC plan for on the site storage of oil and diesel fuel. Secondary containment was properly constructed with earthen berms to control spills in conjunction with properly installed posting and safety devices.

The Mexican Hat SPCC plan addresses requirements for spill response, reporting, and secondary spill containment systems for bulk chemical storage areas. Prior to 1989, the Mexican Hat site had designed and constructed earthen berms around existing above-ground storage tanks and around oil drum storage areas. These secondary containment systems are designed to provide adequate capacity to control spills. In addition, SPCC plans for inspecting berms, detecting spills, emergency spill response, and spill cleanup have been developed for fuel and oil storage areas. 
During Phase II operations at the Rifle site, above-ground storage tanks that contain diesel fuel have been used on the site. As a secondary containment system, an earthen berrn was constructed around all storage areas at the disposal site to provide adequate capacity to control spills.

\section{Septic Tanks}

The Ambrosia Lake site utilizes portable facilities for sanitary purposes. The Falls City site utilized septic systems for the office facilities, which were installed and are maintained per local code. The Grand Junction site uses the local publicly-owned treatment works for all sanitary sewage. A septic tank was installed at the processing site to contain grey water from sanitary facilities in relocated office trailers. Sewage systems were installed to local code at the processing site and disposal sites for the Gunnison site. The Mexican Hat site has one septic tank and drain field in use. The Navajo Office of Environmental Health has jurisdiction. There is a septic tank located near the office trailers on the New Rifle processing site. It is been maintained per state and local requirements.

\section{Surface Water and Groundwater Monitoring}

Surface waters adjacent to UMTRA sites are monitored quarterly and during storms that cause runoff from the sites. Water samples are analyzed for Ra-226 and Th-230. This monitoring is not performed to assess the quality of the water, but to monitor the effects of construction activities. Surface water is sampled at the Grand Junction, Gunnison, Rifle, and Falls City sites. The sample results are compared to previous results and also to guidelines given in DOE Order 5400.5 .

Surface waters in the vicinity of the sites are also monitored for constituents listed in the EPA groundwater standards. This sampling is performed to monitor the quality of surface waters near the sites.

Groundwater monitoring is also conducted routinely to observe changes in groundwater quality prior to, during, and after remedial action. Groundwater samples are analyzed for major ions and the parameters listed in the EPA groundwater standards. Annual water sampling and analysis plans are prepared for all UMTRA sites, including those where surface remedial action has been completed or not yet begun. 



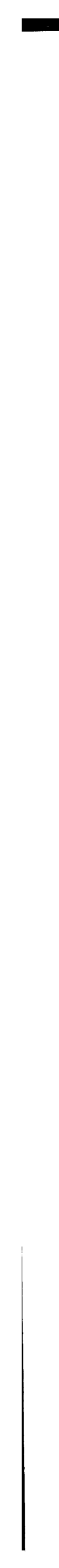

